Discussion Paper No. 04-64

\title{
GPD-linked Bonds as a Financing Tool for Developing Countries and Emerging Markets
}

Michael Schröder, Friedrich Heinemann,

Susanne Kruse, Matthias Meitner

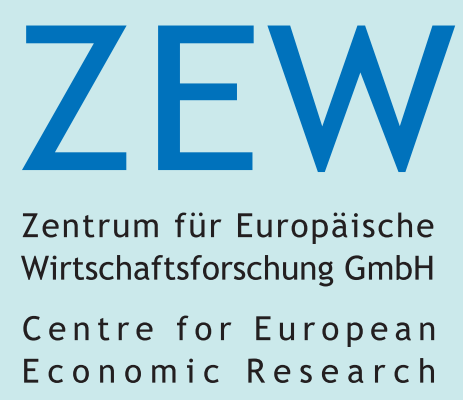


Discussion Paper No. 04-64

\title{
GPD-linked Bonds as a Financing Tool for Developing Countries and Emerging Markets
}

\author{
Michael Schröder, Friedrich Heinemann, \\ Susanne Kruse, Matthias Meitner
}

Download this ZEW Discussion Paper from our ftp server:

ftp://ftp.zew.de/pub/zew-docs/dp/dp0464.pdf

Die Discussion Papers dienen einer möglichst schnellen Verbreitung von neueren Forschungsarbeiten des ZEW. Die Beiträge liegen in alleiniger Verantwortung der Autoren und stellen nicht notwendigerweise die Meinung des ZEW dar.

Discussion Papers are intended to make results of ZEW research promptly available to other economists in order to encourage discussion and suggestions for revisions. The authors are solely responsible for the contents which do not necessarily represent the opinion of the ZEW. 


\section{Non-Technical Summary}

The paper examines the applicability of bonds linked to gross domestic product (GDP) for the financing of developing countries and emerging markets. GDP-linked bonds are bonds of which the coupon and/or the redemption payments are tied to the GDP of the issuing country. The study encompasses four parts: (1) a survey amongst financial experts, (2) the simulation of GDP-linked bond prices, (3) empirical analyses of their pricing and cash flow sensitivities as well as of their behaviour in a portfolio context and (4) an examination of the usefulness of a partial public guarantee of payments.

First, a broad survey amongst potential future investors as well as issuing-side capital market participants is conducted in order to properly assess the prospects of success of this new type of bond. The main result of this survey is that under certain conditions GDP-linked bonds can be successfully issued and traded on international capital markets. They might be an appropriate financing instrument for countries that currently do not have access to capital markets. Typical investors are, above all, different kinds of institutional investors.

The second step is a simulation of prices of GDP-linked bonds. This simulation is conducted based on existing government bonds from potential issuer countries. Depending on the type of bond, prices are computed by combining the straight bond and a forward on GDP (investors fully participate in the development of the GDP) or by combining the straight bond and an option on GDP (investors face a floor on the payments they receive).

In the third part, it is shown that GDP-linked bonds outperform straight bonds if there is a surprising increase in GDP after the date of issuance, and underperform straight bonds if GDP declines unexpectedly. This is due to the changing cash flows of GDP-linked bonds after the shock and the accompanying enhancement/ degradation of the effective yield. Accordingly, a country faces higher total payment duties if GDP rises surprisingly after the date of issuance and faces lower payment duties if GDP falls unexpectedly.

Another result is that the returns for all the types of GDP-linked bonds taken into account correlate highly with the returns on the underlying straight bond. A regression analysis also provides evidence that GDP-linked bonds can in most cases be seen as a close substitute to the underlying straight bond. Finally, using a portfolio optimisation approach in the Markowitz mean-variance framework, it can be shown that international investors will usually not accept high risk premiums when they think about including the GDP-linked bond into an international bond portfolio. 
An important general conclusion can be drawn from the latter result: GDP-linked bonds might be chosen by investors if the GDP of the issuing country has a negative or low positive correlation with the GDP of the reference region of the investor. If the investor holds an internationally well diversified bond portfolio, the correlations with world GDP are relevant. With respect to this, possible issuer countries could be e.g. Bangladesh, Egypt, India, Pakistan, Syria and Vietnam.

The analyses conducted in part four of this study show that the idea of a GDP-linked bond is in no sense conditional on a public guarantee although partial guarantees might be appealing for certain risk-averse investor groups (such as life insurance companies). It may be worth considering a partial guarantee if a country is within close reach of capital market access. Any guarantee scheme applied in the context of GDP-linked bonds should have a much simpler approach compared to the recent Policy Based Guarantees favouring bonds from Argentina and Colombia. 


\title{
GDP-linked Bonds as a Financing Tool for Developing Countries and Emerging Markets
}

\author{
Michael Schröder ${ }^{1}$, Friedrich Heinemann ${ }^{1}$, Susanne Kruse ${ }^{2}$, Matthias Meitner $^{1}$
}

\author{
September 2004
}

\begin{abstract}
:
The paper examines the applicability of GDP-linked bonds for the financing of developing countries and emerging markets. GDP-linked bonds are bonds of which the coupon and/or redemption payments are tied to the GDP of the issuing country. The study encompasses a detailed empirical analysis of their pricing behaviour, the pricing sensitivities to changes in GDP, and of their behaviour in a portfolio context is conducted. A survey amongst potential investors as well as issuing-side capital market participants assesses the prospects of success of this new type of bond. Finally, the usefulness of a partial public guarantee of payments is examined. The paper provides evidence under which circumstances, for which investors and for which countries GDP-linked bonds might be an appropriate investment vehicle.
\end{abstract}

JEL-Classifications: H81, G18, O19

Keywords: GDP-linked bonds, bonds, development finance, public finance

\section{Contact:}

Michael Schröder

Centre for European Economic Research (ZEW)

P.O. Box 103443

D-68034 Mannheim, Germany

Email: schroeder@zew.de, Tel.: +49/621/1235-140, Fax:-223

${ }^{1}$ Centre for European Economic Research (ZEW), Mannheim, Germany.

Department "International Finance, Financial Management, and Macroeconomics".

${ }^{2}$ Fraunhofer Institut für Techno- und Wirtschaftsmathematik (Institute for Industrial Mathematics), Kaiserslautern, Germany 


\section{Introduction ${ }^{1}$}

Developing countries and emerging markets need significant capital inflows from abroad to finance domestic public investments and, in particular, to build-up their public infrastructure. This is an important prerequisite for boosting long-term economic growth.

These countries typically exhibit a relatively high risk of default which is mirrored by low ratings from international rating agencies such as e.g. Moody's and Standard \& Poor's. Empirical studies have found that this default risk depends significantly on the short- and long-term development of a country's gross domestic product (GDP). This means, that investors in emerging market bonds are affected by default risks which fluctuate in relation to news about future GDP.

A common instrument for financing public debt is the fixed-coupon bond ("straight bond"). The interest and redemption payments on these bonds are fixed in advance and are therefore independent of the state of the economy. As a consequence changes in the business cycle and long-term growth prospects do not translate into changes in a country's debt service.

A recent study by Borensztein and Mauro $^{2}$ has renewed interest in so called GDPlinked bonds. ${ }^{3}$ In the Borensztein/Mauro definition, these bonds tie the coupon of a bond to the year-on-year changes of GDP: if economic growth is low, the bond coupon decreases; if GDP rises strongly, so does the coupon. Thus, in contrast to straight bonds, GDP-linked bonds take explicit account of GDP development rather than simply doing so implicitly in relation to the expected default risk of market participants.

In contrast to Borensztein/Mauro (2002), our study covers a much wider range of bonds. GDP-linked bonds cannot only be tied to short-term variations in GDP but also to long-term changes: coupon and/or redemption could be linked to the development of GDP during the time to maturity. Thus, GDP-linked bonds are able to consider temporary business cycle effects (as in Borensztein/Mauro), but also the medium- and long-term development of the economic conditions of the issuing country.

The study has been commissioned by the German Ministry of Finance, Berlin.

2 See Borensztein/Mauro (2004).

3 Furthermore, Argentina's offer to its investors to issue bonds that are linked to the economic growth eventually has brought some practical relevance to GDP-linked bonds; see Financial Times (2004) for an up-to-date discussion of the Argentine case and the need for GDP-linked bonds in public finance in general. 
Our study also considers the possibility of public guarantees provided by an international organisation such as the World Bank that partly insure the default risk of the bond. Although such public guarantees are not a necessary attribute of GDPlinked bonds, they could help to introduce these bonds on international capital markets.

The remainder of the paper is organised as follows: section 2 deals with the theoretical basics and with the results from a survey among potential investors and other financial experts. Section 3 presents the results of a quantitative analysis of GDP-linked bonds, including their pricing behaviour, the price sensitivities to GDP changes and their behaviour in a portfolio context. Section 4 comprises an assessment of the usefulness of a (partial) public guarantee to accompany a GDPlinked bond issue. Finally, section 5 summarizes the main results.

\section{Characteristics of GDP-Linked bonds and Investors}

\subsection{Theoretical Aspects}

Past experience with similar financial instruments

The idea of linking bond payments to macro-economic data is not totally new. This topic has been discussed in the theoretical literature since the early $1980 \mathrm{s.}^{4}$ In practice, however, only inflation-indexed bonds have become widely accepted. For example, high volumes of such securities have been issued by several developed countries like Great Britain, USA, Australia, Canada and France. ${ }^{5}$ Financial instruments linked to economic performance, however, have very little significance in practice: Mexico and Venezuela issued some Brady Bonds linked to the oil price (so called Value Recovery Rights); Only Costa Rica, Bosnia-Herzegovina, and Bulgaria explicitly issued Brady Bonds linked to GDP.

\section{Classification of GDP-linked bonds within the framework of financial theory}

From the perspective of financial theory, GDP-linked bonds can be regarded as a form of mezzanine capital or as hybrid financial instruments. While the basic structure resembles debt capital - capital loaned for a limited time period, periodical coupon payments, redemption at maturity, no ownership rights associated with these securities - they exhibit certain equity characteristics as well. The dependence of the amount of payments on the performance of the country - central characteristic of GDP-linked bonds - is in fact typical of the profit participation function of equity.

4 See Bailey (1983), Shiller (1993), Price (1997), Brynjolfsson/Fabozzi (1999), Haldane (1999), Drèze (2000), Caballero (2001), Borensztein/Mauro (2004).

5 See Brynjolfsson/Fabozzi (1999), pp. 183-237. 
To better understand how GDP-linked bonds work, it is helpful to replicate this new financing instrument along the lines of conventional financial instruments. In this context it can be shown that GDP-linked bonds can be synthetically created by combining conventional government bonds and financial derivatives. At its simplest, the financial derivative used is a forward on the development of the country's GDP. In modelling, it should be noted that a separate forward must be created for each individual payment to be indexed. Depending on the structure of the GDP-linked bonds, a call option for the investor can be used instead of the forward, which creates a floor on the coupon payment and/or the capital repayment.

There are two typical consequences of this possibility of a synthetic creation of GDP-linked bonds. First, investors can basically rebuild these bonds by using a government bond and an appropriate forward contract. Second, existing GDP-linked bonds can principally be separated into the two components straight bond and forward, which can then be traded independently from each other. The prerequisite for both scenarios is, however, that a developed market for economic derivatives these are financial derivatives of which the underlying is an economic variable such as the GDP - exists. The Deutsche Bank and Goldman Sachs currently try to establish such a market. ${ }^{6}$

\subsection{Results of the Interviews with Financial Experts}

In addition to theoretical considerations it is important to ask market participants and - in particular - potential future investors in GDP-linked bonds in order to get a proper assessment of the prospects of success of this new type of bond. 21 interviews which were therefore carried out in which the interview partners (from private and public banks, investment companies, insurance companies, rating agencies, and tax advisors) provided detailed information about what they considered to be desirable GDP-linked bonds characteristics.

The major result of these 21 interviews - conducted either face-to-face or by phone - is that under certain conditions GDP-linked bonds can be successfully issued and traded on international capital markets. ${ }^{7}$

\section{- Potential investors}

GDP-linked bonds are a suitable investment vehicle particularly for institutional investors such as insurance companies, pension funds, several bond funds and hedge funds. These types of investor are able to understand the relatively complex product characteristics and to price bonds correctly. Nevertheless, GDP-linked bonds will not get much weight in the portfolios of these institutional investors but will rather

6 See www.economicderivatives.com

7 The detailed results of these interviews are available upon request from the authors. 
be used for diversification. The existence of a third-party (partial) payment guarantee crucially determines the circle of potential investors. To put it more precisely, especially insurance companies, pension funds and bond funds specialised on industrial countries favour a guarantee attached due to their general preference for investment-grade bonds.

Hedge funds and emerging market bond funds could become the typical investors for this product as far as no legal or contractual restrictions exist. Dependent on the characteristics of the issuer country, the investment objectives and constraints of the funds, they could possibly be interested in building long-term strategic positions in these countries via GDP-linked bonds. Both types of investors do not call for a thirdparty guarantee of payments.

Due to their typically long investment horizons life-insurance companies and pension funds might be interested in investing in GDP-linked bonds since long-term buy-and-hold strategies could help to reduce the risk of business cycle volatility. Moreover, GDP-linked bonds can be an appropriate investment for these companies in order to participate in the development of strongly growing countries.

However, it has to be noticed that there are some minimum standards that GDPlinked bonds have to fulfil to meet the investment criteria of some groups of institutional investors. For example, German life-insurance companies and pension funds would only invest in GDP-linked bonds if they were not rated below investment grade-level (e.g. at least BBB- in terms of Standard\&Poor's). It is also appreciated that these bonds are denominated in euro since most of their liabilities have to be repaid in euro. Additionally, some legal restrictions are imposed for these companies by the "Regulations governing Investments of Regulated Assets of Insurance Companies and Pension Funds": 8 Such restrictions are e.g. the nonnegativity of the coupon payments and the redemption at par value. ${ }^{9}$ It has to be assumed that international life-insurance companies and pension funds face similar restrictions.

Private investors will probably not hold GDP-linked bonds directly given that their pricing is more complex than that of straight bonds. In some countries, e.g. in Germany, private investors would also suffer from a tax disadvantage as GDPlinked bonds are regarded as so called financial innovations. This means that the capital gains as well as the coupon are taxed which is in contrast to fiscal treatment of straight bonds where only coupon payments are taxable. ${ }^{10}$ In fact, in other

\footnotetext{
8 See Bafin (2001).

9 These restrictions do not apply for 5 percent of the assets under management, which can be freely invested due to a saving clause.

10 Assumption: investors hold the bonds for a period longer than 12 months.
} 
companies, such as France, Great Britain and the USA both capital gains and coupons are taxes, too. However, private investors are not fiscally disadvantaged because these two payment components are also taxed when holding straight bonds.

Nevertheless, the interviews also revealed that private investors can be potential investors when holding GDP-linked bonds indirectly via mutual funds, even though the potential tax disadvantages do not disappear.

GDP-linked bonds could be potential investment vehicles in Islamic countries. Islam prohibits Riba, which is an interest on money-lending. This gives rise to the fact that most straight bonds are not an appropriate investment and financing tool. GDPlinked bonds, however, might possibly overcome this problem since the payments are linked to some form of operating activity (which is generally allowed in Islamic finance). Nevertheless, whether different forms of GDP-linked bonds actually comply with Islamic finance has to be examined by Islamic scholars case-by-case.

The interviews furthermore revealed that, in general, investors living in the issuing country (both private and institutional) represent a huge demand potential for these bonds.

GDP-linked bonds are not an appropriate investment vehicle for the proprietary trading department of commercial banks due to the expected limited liquidity of that product. These securities are also not interesting for the loan department of banks since they prefer a payment linkage to a specific project performance rather than a country performance.

\section{- Features of the bond}

The central aim of this section of the questionnaire was to figure out a certain design of GDP-linked bonds that leads to the highest possible marketability of these instruments.

\section{$\underline{\text { Simplicity of Construction }}$}

GDP-linked bonds should be constructed as simply as possible. The easier they are to understand and price, the higher the demand for these bonds. To put it more precisely, the interviews showed that capital markets would prefer a construction that is quite similar to the construction of inflation-indexed bonds since the markets have already made some experience with these instruments.

\section{Economic indicator for Indexing}

The aim of these bonds is to link the payments of the issuing country to its economic performance and therefore to its paying ability. In this context, the GDP of a country has to be regarded as the most obvious indicator to fulfil that requirement. However, 
there are basically several performance variables other than the GDP that could also serve as an indexing indicator. These are for example the export earnings, tax revenues, and also certain key commodity prices. Moreover, those instruments can be linked to nominal or real GDP. The interviewees clearly preferred a GDPlinkage. They reckoned that, with regard to the aim of these bonds, a linkage to nominal GDP is appropriate if the bonds are denominated in local currency. However, a linkage to real GDP is more suitable if the bonds are denominated in hard currency (dollar, euro, yen), in order to prevent the issuing country from the double-charge of balancing the inflation rate and paying for an associated depreciation of the local currency.

\section{Indexing method}

It is possible to index coupon payments and/or capital repayments. In theory, no preferred method of indexing exists. In practice, the indexing method applied for inflation-indexed bonds is well understood and accepted by capital markets. Thus, this mechanism is also recommendable for GDP-linked bonds.

\section{Payment floors and ceilings}

In the simples variant of GDP-linked bonds the investor fully participates in both a positive GDP development and a negative GDP development of the issuing country. This variant is best replicated by a combination of a straight bond and a forward contract. However, if it better satisfies the objectives and needs of the issuing country or of the investor, a floor or ceiling may also be applied to coupon and/or capital repayments. In the case of a payment floor (the investor only participates in the GDP development if the GDP exceeds a certain threshold), the construction of the bonds resembles a combination of a straight bond and a long call option on GDP. A cap on the payments (the investor only participates in the GDP development if the GDP falls short of a certain threshold) can be synthetically created by a straight bond and a short put option from the investor's perspective.

A result of the interviews is that a floor is especially interesting for issuing countries if they are in a stage of low growth since they can generate additional income by collecting the option premium. From the position of potential investors, however, a floor is usually not very attractive because of the implicit reduction of the yield of the GDP-linked bonds (typical investors in these securities exhibit rather low degrees of risk aversion). The inclusion of a ceiling has not found any support at all in the interviews. In this context it also has to be considered that every additional characteristic affects the performance of the bond, complicates the pricing of GDPlinked bonds and reduces demand of investors. 


\section{Time to maturity}

A balance must be struck between long times to maturity, which permit the whole economic cycle of a country to be considered, and shorter times to maturity, which result in less default risk for investors. In general, the interviewees did not regard the determination of the time to maturity as a crucial point in constructing the GDPlinked bonds.

\section{Currency}

The bond can be issued in local or hard (dollar, euro, yen) currency. The only point to consider is that the local currency must be hedgeable at international capital markets. However, if the bond is denominated in local currency, foreign investors will bear an additional currency risk or additional hedging costs. A hard currency is preferable if the bond mainly focuses on international investors while the local currency is more appropriate if it mostly focuses on domestic investors.

\section{- Public guarantee of payments}

While a partial public guarantee of coupon payments and/or redemption by e.g. an international organisation such as the World Bank reduces the default risk borne by investors, it also decreases the expected returns. Thus, a public guarantee might be preferable for some investors (e.g. insurance companies) as the guarantee increases the rating of the bond. Other investors, such as emerging market bond funds, will prefer to bear a higher default risk and earn a correspondingly higher risk premium. Regarding the country's perspective, a public guarantee is an appropriate feature for those issuers that have little or no capital market history. In such cases, countries can build up reputation with the guarantee, which, in turn, gives rise to an increasing probability of a successful bond placement. A more detailed description of the public guarantee issue can be found in section 4 .

Principally, it is also conceivable that a private bond insurance takes the place of that public guarantee. An example of a company that offers such bond insurance is the Asian Securitization and Infrastructure Insurance Ltd. (ASIA Ltd.), which is partially owned by the Asian Development Bank. A problem with such a bond insurance is that the factual country risks might not be thoroughly known yet. This might cause the bond insurance companies to initially charge high premiums for that service or even to refuse to offer that service.

\section{- Bond issue and the secondary market}

\section{Target countries}

All developing countries, all emerging market countries and, as a matter of course, all low-income transition countries are potential issuers of GDP-linked bonds. However, some countries may not be suited as issuers due to their inability to access 
the capital market as a result of inadequate administrative infrastructure or social instability (these characteristics mainly describe what is referred to as the political risk in a sovereign rating process). Irrespective of the use of GDP-linked bonds for development financing, as examined in this project, it should be noted that, in principle, high-rated industrial nations are also potential issuers. However, these countries are not expected to be interested in bearing the relatively high costs associated with the issuance of a new financing instrument (compared to the costs of the issuance of a financing instrument that is already well known at capital markets).

GDP-linked bonds are especially interesting for countries that stand at the threshold of capital market accessibility. For these countries, GDP-linked bonds can open the door to the capital market since it attracts some groups of investors that would not invest in a straight bond of that country. It is worth noting that once capital market reputation is build up, countries principally also have the possibility to issue other forms of financing instruments. In that context, GDP-linked bonds can be seen as a means of cultivating the capital market accessibility of development or emerging countries.

\section{Market liquidity}

To achieve a high liquidity of a GDP-linked bond issue (which in turn lowers the liquidity premium of that bond) an issuing volume of about $€ 500$ million -1 billion is desirable. Such an issuing volume is usually too high for single target countries. To overcome that problem, a basket-issue might be a conceivable solution (a joint issue of several target countries). However, for some investors a high liquidity (e.g. insurance companies, pension funds) is not so important. If the issue mainly addresses these types of investors, a low-volume private placement is also imaginable.

\section{Monitoring calculation of indicators}

In order to enhance the credibility of the bond, an international financial institution (such as the World Bank) could monitor the calculation of real GDP to ensure its accuracy. As a low cost alternative to monitoring, the issuing country could subscribe to the IMF's Special Data Dissemination Standard (SDDS).

\subsection{Conclusions on the Results from the Interviews}

Table 1 summarises the main results of the interviews and of our own conclusions.

In general, emerging market bond funds and hedge funds may be interested in investing in GDP-linked bonds depending on the GDP-linked bond characteristics in each case. 
As regards product characteristics, the interviewees largely agree that institutional investors would be able to price GDP-linked bonds. Nevertheless, it would be advisable to have a construction which is as simple and transparent as possible in order to facilitate a positive reception by the capital market and above all liquid trading.

Table 1: Important characteristics of GDP-linked bond, classified by types of investor

\begin{tabular}{|c|c|c|c|}
\hline & $\begin{array}{l}\text { Life Insurers and } \\
\text { Pension Funds } \\
\text { (restricted assets) }\end{array}$ & $\begin{array}{l}\text { International Mutual } \\
\text { Bond Funds }\end{array}$ & $\begin{array}{l}\text { Banks and Hedge Funds (as } \\
\text { well as life insurers and } \\
\text { pension funds (free assets)) }\end{array}$ \\
\hline Rating & $\begin{array}{l}\text { Investment grade (at } \\
\text { least BBB-). }\end{array}$ & \multicolumn{2}{|c|}{$\begin{array}{l}\text { Any rating. Many emerging market investors prefer low } \\
\text { ratings in order to increase the expected returns. }\end{array}$} \\
\hline $\begin{array}{l}\text { Liquidity of GDP- } \\
\text { linked bonds }\end{array}$ & $\begin{array}{l}\text { Not so important. } \\
\text { Private placement also } \\
\text { possible. }\end{array}$ & Very important. & $\begin{array}{l}\text { Very important. Exceptions: loan } \\
\text { exposures of banks, hedge funds, } \\
\text { life insurers and pension funds. }\end{array}$ \\
\hline $\begin{array}{l}\text { Issuing Volume (to } \\
\text { ensure market } \\
\text { liquidity) }\end{array}$ & \multicolumn{3}{|c|}{$\begin{array}{l}\text { At least } € 250 \text { million, preferably } € 500-1000 \text { million. A basket approach (= joint } \\
\text { issuance by two or more countries) might be an alternative in some cases. }\end{array}$} \\
\hline $\begin{array}{l}\text { Securities Exchange } \\
\text { Listing }\end{array}$ & Necessary. & \multicolumn{2}{|c|}{ Not necessary, but advisable. } \\
\hline $\begin{array}{l}\text { Public Guarantee of } \\
\text { the Payment Flows }\end{array}$ & $\begin{array}{l}\text { Needed to achieve an } \\
\text { investment grade } \\
\text { rating. }\end{array}$ & \multicolumn{2}{|c|}{$\begin{array}{l}\text { In principle not important, could even be counter- } \\
\text { productive, since the guarantee would cause the expected } \\
\text { return to be lower. Useful to ensure marketability in the } \\
\text { case of countries without access to capital markets }\end{array}$} \\
\hline Type of Indexing & $\begin{array}{l}100 \% \text { of nominal } \\
\text { amount must be } \\
\text { repaid. }\end{array}$ & \multicolumn{2}{|c|}{ Any type. Forward or call on GDP would be suitable. } \\
\hline $\begin{array}{l}\text { Floor of the Coupon } \\
\text { Payment }\end{array}$ & $\begin{array}{l}\text { Coupon must not } \\
\text { become negative. }\end{array}$ & \multicolumn{2}{|c|}{ Floor may be useful to safeguard investors. } \\
\hline $\begin{array}{l}\text { Ceiling for Coupon } \\
\text { Payment }\end{array}$ & \multicolumn{3}{|l|}{ Not useful. } \\
\hline Currency & $\begin{array}{l}\text { Domestic currency } \\
\text { needed. }\end{array}$ & \multicolumn{2}{|c|}{$\begin{array}{l}\text { In principle not important. However, local currency } \\
\text { should be hedgeable. Local currency above all when the } \\
\text { bond is marketed in the country itself, hard currency for } \\
\text { international issues. }\end{array}$} \\
\hline $\begin{array}{l}\text { Option of Shortening } \\
\text { / Extending the Time } \\
\text { to Maturity }\end{array}$ & \multicolumn{3}{|c|}{$\begin{array}{l}\text { Not advisable. Needlessly complicates the evaluation of the bond and quite } \\
\text { considerably reduces its usefulness to the investor. }\end{array}$} \\
\hline Time to Maturity & \multicolumn{3}{|c|}{$\begin{array}{l}\text { Not fixed. Should cover at least one business cycle (about 7-10 years). Should be } \\
\text { shorter (up to five years) for a country with a poor rating. }\end{array}$} \\
\hline Type of Country & \multirow{2}{*}{\multicolumn{3}{|c|}{$\begin{array}{l}\text { Countries which have previously had very little access to the capital market. } \\
\text { Important as a rule. The measuring of GDP should be monitored by a neutral } \\
\text { external organisation. Adoption of Special Data Dissemination Standard (SDDS). }\end{array}$}} \\
\hline $\begin{array}{l}\text { Monitoring of GDP } \\
\text { Statistics }\end{array}$ & & & \\
\hline
\end{tabular}

A public guarantee of payment flows provided, for example, by the World Bank is necessary only to the extent that this would ensure the marketability of GDP-linked bonds. Insurers and pension funds do however attach importance to an investment grade rating. If GDP-linked bonds are to be targeted at these types of investors, a guarantee is needed which at least ensures a rating of BBB-. 
Suitable debtor countries are above all countries without access to the capital market. A joint issue by several countries could be helpful in order to ensure a sufficient issue volume. It would also be advisable to choose a hard currency as the issuing currency.

In order to improve marketability it would be particularly important to ensure that national account statistics were monitored by an external, neutral institution such as the IMF or World Bank. This is the only way of ensuring adequate confidence in the reliability of the figures provided by the debtor country. A low cost alternative would be the adoption of the IMF's Special Data Dissemination Standard (SDDS) by the debtor country.

Extensive marketing activities are also very important if GDP-linked bonds are to be successful on the market. It would be very helpful if international organisations such as the IMF, the World Bank or the UN were to actively support the issue of GDPlinked bonds and seek to persuade the major groups of investors to purchase GDPlinked bonds.

\section{Quantitative Assessment of GDP-linked Bonds}

\subsection{Simulation of GDP-linked Bond Prices}

As GDP-linked bonds are a new class of bond, pricing behaviour and performance cannot be investigated directly. Therefore, in this study, prices of different types of GDP-linked bonds are simulated and compared to straight bonds and international bond indices. ${ }^{11}$

All simulated GDP-linked bonds are connected to real GDP. The calculations are based on quarterly data. The following two types of GDP-linkage of the coupon have been considered:

Type 1: $\operatorname{Coupon}(t)=\frac{\text { FixedCoupon }(t) * G D P(t)}{G D P\left(t_{0}\right)}$

Type 2:

Coupon $(t)=\max \left[\right.$ FixedCoupon $(t)+$ GDPgrowth $(t)-$ average GDPgrowth $\left.\left(t_{0}\right) ; 0\right]$

The period $t$ refers to the date of the coupon payment whereas $t_{0}$ indicates the date of the issuance of the bond.

11 A detailed description of the mathematical proceeding (in German) can be found in Korn/Kruse (2004). 
With respect to type 1, the coupon is equal to a fixed coupon times the GDP in the current period $t$, divided by the GDP-value at the date of the bond issuance. Thus, the coupon payment is linked to the change in economic development during time to maturity. The coupon is always non-negative.

The second type of coupon (type 2) links a fixed coupon with quarter-to-quarter changes in GDP (= GDPgrowth). The average quarter-to-quarter GDP growth rate at the date on which the bond is issued is calculated for the 10 year period $(=40$ quarters) prior to $t_{0}$ and held fixed afterwards. This average figure serves as a correction term for the adjustment of the coupon payments. The type 2-coupon payments are either equal to the formula (if the value is positive) or zero.

In contrast to the proposal made by Borensztein and Mauro ${ }^{12}$ the type 2 coupon construction uses quarter-to-quarter changes in GDP, whereas Borensztein/Mauro propose the year-on-year changes. The use of type 2 has the advantage of a faster reaction of the coupon payments to GDP changes compared to the proposal of Borenstzein/Mauro. But when yearly data are used in the type 2-formula (instead of quarterly data) both approaches are identical.

In a new version of their paper ${ }^{13}$, Borensztein and Mauro propose two additional linkage mechanisms which are much more complicated to price. As this would certainly impede the reception of GDP-linked bonds by the capital market, our simulations are only based on the two types of coupon-linkage described above.

In addition, redemption payments could also be linked to economic development. Our simulations consider the following three types of redemption payments:

1. Redemption at par. In this case, only the coupon payment is linked to GDP, either to GDP development during time to maturity (type 1 ) or to the quarter-to-quarter change (type 2).

2. Redemption is linked to GDP development during time to maturity. The redemption payment is therefore symmetrically linked to GDP development and can be above or below par.

3. As above (no. 2), with the difference that redemption payment is always equal or above par value. The floor has been constructed by using a call option on GDP development. This variant is particularly useful for a GDP-linked bond with a short time to maturity.

\footnotetext{
12 See Borensztein/Mauro (2002).

13 See Borensztein/Mauro (2004)
} 
In cases 2 and 3, the coupon payment is also linked to GDP during time to maturity (type 1).

These different GDP-linked bond variants are simulated either with or without a public guarantee of redemption payments by an international organisation. In the case of a public guarantee, $70 \%$ of the redemption value is insured (as an example). Thus, we simulate the prices of 8 different types of GDP-linked bond:

- BOND1: Coupon linked to GDP development (i.e. relative to GDP at date of issuance), redemption at par $(=100)$.

- BOND2: Coupon and redemption linked to GDP development (i.e. relative to GDP at date of issuance).

- BOND3: Coupon and redemption linked to GDP development (i.e. relative to GDP at date of issuance). In addition call option to guarantee redemption which is at least at par.

- BOND4: Coupon linked to GDP growth (i.e. quarter-to-quarter change of GDP), redemption at par.

- BOND5 to BOND8: as above BOND1 to BOND4, but combined with a partial public guarantee $(70 \%)$ of the redemption payment.

\section{Data}

The GDP-linked bond price simulations are based on selected historical government bonds issued by different countries. Using the interest rate and bond database of Professor Bühler from the University of Mannheim, we chose 8 bonds from 5 countries: Brazil, Indonesia, Mexico, Turkey and Venezuela. All bonds are denominated in German mark or euro. Table 2 gives an overview of these bonds.

Criteria for the selection of these government bonds have been:

- potential GDP-linked bond issuer countries,

- different world regions,

- different time periods,

- availability of bond prices in the interest rate and bond data base of Prof. Bühler, University of Mannheim.

To calculate prices of synthetic GDP-linked bonds, the simulations use the prices of these government bonds. Furthermore, quarterly GDP data for the countries provided by the IMF were applied. If these quarterly data were not available we approximated them by interpolation of yearly data. The yearly data are provided by 
the World Bank. Finally, we used an approximated term-structure of interest rates for zero-coupon bonds, determined on the basis of monthly data and provided by the Deutsche Bundesbank, for our calculations. ${ }^{14}$

Table 2: Selected Government Bonds as Basis for GDP-linked Bond Price Simulations

\begin{tabular}{|l|c|c|c|c|c|c|c|}
\hline Country & SIN & $\begin{array}{c}\text { Date of } \\
\text { Issuance }\end{array}$ & $\begin{array}{c}\text { Start of } \\
\text { Time } \\
\text { Series }\end{array}$ & Maturity & $\begin{array}{c}\text { End of } \\
\text { Time } \\
\text { Series }\end{array}$ & $\begin{array}{c}\text { Coupon } \\
\text { (in \%) }\end{array}$ & $\begin{array}{c}\text { Current } \\
\text { Rating }\end{array}$ \\
\hline Brazil & 614414 & 5.7 .00 & 18.8 .00 & 5.7 .05 & 30.12 .02 & 9,0 & B+ \\
\hline & 607749 & 24.1 .01 & 24.1 .01 & 24.1 .11 & 30.12 .02 & 9,5 & B+ \\
\hline Indonesia & 485500 & 27.10 .88 & 29.12 .88 & 27.10 .93 & 11.10 .93 & 6,375 & B \\
\hline Mexico & 402280 & 31.3 .91 & 23.9 .92 & 13.3 .96 & 26.2 .96 & 10,5 & BBB- \\
\hline & 130890 & 29.1 .96 & 2.4 .96 & 29.1 .03 & 30.12 .02 & 10,375 & BBB- \\
\hline Turkey & 485678 & 8.11 .88 & 7.12 .88 & 8.11 .95 & 23.10 .95 & 6,5 & B+ \\
\hline & 129180 & 21.8 .95 & 21.12 .95 & 21.8 .98 & 5.8 .98 & 8,0 & B+ \\
\hline Venezuela & 411810 & 15.10 .93 & 20.12 .93 & 15.10 .00 & 29.9 .00 & 8,25 & B- \\
\hline
\end{tabular}

Calculation and simulation of fundamental variables

To match the term structure of interest rates of the Deutsche Bundesbank with the market prices of the existing government bonds, our simulations imply a certain default probability that does not depend on the time horizon. This default probability is calculated as follows:

default probability $(t)=1-\frac{\text { market price of the existing bond }(t)}{\text { theoretical price of thebond }(t)}$

The theoretical price ("clean price") equals the theoretical dirty price (future payments discounted at the rates from the term structure of interest rates provided by the Deutsche Bundesbank) less accrued interest. That default probability is considered in the following price simulations of GDP-linked bonds, which assures that GDP-linked bonds always exhibit the same default probability as the respective government bond of table 2 .

The GDP for a certain trading day is calculated by linear interpolation between two disclosure dates:

14 Source: http://www.bundesbank.de/stat/zeitreihen/index.htm 


$$
\begin{aligned}
& \text { GDP }(\text { trading day }) \\
& =G D P([m+1] \text { quarters ago }) \\
& +\frac{(\text { days after the beginning of the quarter }-1) \cdot(G D P([\mathrm{~m}] \text { quarters ago })}{\text { days in the current quarter }} \\
& -\frac{\mathrm{GDP}([m+1] \text { quarters ago }))}{\text { days in the current quarter }}
\end{aligned}
$$

It is assumed that the GDP is disclosed with a lag of $m$ quarters. For the countries under examination the actual disclosure lags are as follows:

\begin{tabular}{|lc|}
\hline Country & Disclosure Lag \\
\hline Brazil & 1 quarter \\
Indonesia & 1 quarter \\
Mexico & 3 quarters \\
Turkey & 3 quarters \\
Venezuela & 1 quarters \\
\hline
\end{tabular}

The quarter-to-quarter change of the GDP (which is a necessary parameter for the calculation of the 'type 2 coupon linkage' bonds: BOND 4 and BOND 8) is calculated as:

quarter to quarter change $=\frac{G D P(\text { current quarter })-G D P(\text { last quarter })}{G D P(\text { last quarter })}$

A major problem in the price simulations is that no appropriate financial derivatives (with the GDP as underlying) are currently traded at financial markets. That is why our simulations have to rely on variables that are determined via statistical analysis based on the available GDP time series rather than on explicit market parameters. Assuming a log-normally distributed GDP, values for the drift component $\mu$ - the average growth rate of the GDP - and the volatility $\sigma$ of the GDP were estimated based on a 10-year period backwards in time from every trading day. The distribution assumption implies that the GDP behaves strictly positively. Therefore we can apply an analogon to the Black-Scholes-formula for European style Options in our simulations.

\section{Simulation of GDP-linked bond prices}

The assumption of a log-normal distribution of the GDP leads to the following expression for the expectation value of the future GDP in dependence of the current GDP: $E[G D P(t)]=G D P(0) e^{\mu t}$ 
Given that the current trading day equals day $0, t_{c_{i}}$ corresponds to the dates of coupon payment before the trading day, $t_{0}$ is the date of issuance with $G D P\left(t_{0}\right)$ as the GDP at that date, $T$ denotes the maturity date, $p$ is the default probability, $G$ the guaranteed repayment and $c$ the initial coupon, the dirty prices of the different types of bonds are calculated as follows:

BOND1: $P_{B O N D 1}(0)=(1-p)\left(\sum_{i=1}^{n} c \frac{G D P(0)}{G D P\left(t_{0}\right)} e^{(\mu-r) t_{c_{i}}}+100 * e^{-r T}\right)$

BOND2: $P_{B O N D 2}(0)=(1-p)\left(\sum_{i=1}^{n} c \frac{G D P(0)}{G D P\left(t_{0}\right)} e^{(\mu-r) t_{c_{i}}}+100 * \frac{G D P(0)}{G D P\left(t_{0}\right)} e^{(\mu-r) T}\right)$

BOND3:

$P_{B O N D 3}(0)=(1-p)\left(\sum_{i=1}^{n} c \frac{G D P(0)}{G D P\left(t_{0}\right)} e^{(\mu-r) t_{c_{i}}}+100 *\left(e^{(\mu-r) T}+C\left(0 ; G D P(0) ; G D P\left(t_{0}\right)\right)\right)\right)$

with $C\left(0 ; G D P(0) ; G D P\left(t_{0}\right)\right)$ as a European style call option on the change of GDP since issuance with a strike of 1 and a time to expiration $T$. Using the already estimated values for $\mu$ and $\sigma$, the price of that option is determined as:

$C\left(0 ; G D P(0) ; G D P\left(t_{0}\right)\right)=\frac{G D P(0)}{G D P\left(t_{0}\right)} \Phi(d)-e^{-r T} \Phi(d-\sigma \sqrt{T})$ with $d=\frac{\ln \left(\frac{G D P(0)}{G D P\left(t_{0}\right)}\right)+\left(\mu+\frac{1}{2} \sigma^{2}\right) t}{\sigma \sqrt{T}}$

In that formula, $\Phi(x)$ is the standard normal distribution of $\mathrm{x}$.

BOND4: $P_{B O N D 4}(0)=(1-p)\left(\sum_{i=1}^{n} C_{G D P-R a t e}\left(0, t_{c_{i}}\right) e^{-r t_{c_{i}}}+100 * e^{-r T}\right)$

with $C_{G D P-R a t e}\left(0, t_{c_{i}}\right)$ as a forward starting call option that is calculated as:

$C\left(0, t_{c_{i}}\right)=e^{-r t_{c_{i}}}\left(e^{1 / 4} \Phi(d)-X \Phi\left(d-\frac{1}{4} \sigma\right)\right)$ with $d=\frac{-\ln (X)+\frac{1}{4}\left(\mu+\frac{1}{2} \sigma^{2}\right)}{\frac{1}{2} \sigma}$

$X$ is the strike of that option and is determined as:

$X=($ average GDP-growth $+1-$ initial coupon in percent $)$ 
BOND5: $P_{B O N D 5}(0)=(1-p)\left(\sum_{i=1}^{n} c \frac{G D P(0)}{G D P\left(t_{0}\right)} e^{(\mu-r) t_{c_{i}}}+100 * e^{-r T}\right)+p * G$

BOND6: $P_{B O N D 6}(0)=(1-p)\left(\sum_{i=1}^{n} c \frac{G D P(0)}{G D P\left(t_{0}\right)} e^{(\mu-r) t_{c_{i}}}+100 * \frac{G D P(0)}{G D P\left(t_{0}\right)} e^{(\mu-r) T}\right)+p^{*} G$

BOND7:

$P_{B O N D 7}(0)=(1-p)\left(\sum_{i=1}^{n} c \frac{G D P(0)}{G D P\left(t_{0}\right)} e^{(\mu-r) t_{c_{i}}}+100 *\left(e^{(\mu-r) T}+C\left(0 ; G D P(0) ; G D P\left(t_{0}\right)\right)\right)\right)+p^{*} G$

with the same option as described for BOND3.

BOND8: $P_{B O N D 8}(0)=(1-p)\left(\sum_{i=1}^{n} C_{G D P-R a t e}\left(0, t_{c_{i}}\right) e^{-r t_{c_{i}}}+100 * e^{-r T}\right)+p^{*} G$

with the same option as described for BOND4.

These calculations become slightly easier if the trading day and the following date of coupon payment are in the same quarter since then the next coupon is not random but fixed. In that case, for the next coupon payment the expected GDP has to be substituted with the known GDP.

The prices of these GDP-linked bonds were simulated such that the issue price equals the issue price of the respective government bond, which was 100 in all cases under examination. That proceeding ensures that both types of bonds have the same (expected) yield to maturity at the date of issuance.

\section{Total Return Index}

The final step has been the construction of total return indices (TRIs) based on the realized and simulated bond prices. The total return indices include all interest payments and, thus, represent the total return to an investor who invests in a specific bond.

The TRI is calculated as follows: $\operatorname{TRI}(t)=\prod_{t_{c_{i}} \leq t}\left(1+\frac{c\left(t_{c_{i}}\right)}{P\left(t_{c_{i}}\right)}\right) P(t)$

Where $t$ is the trading day, $t_{c_{i}}$ corresponds to the dates of coupon payment before the trading day $t$, and $P($.$) denotes the dirty price of the bond for the respective date. For$ 
the calculation, the simulated prices of GDP-linked bonds as well as the prices of the existing government bonds were used.

\subsection{Evaluation of Cash Flow- and Performance-Sensitivities to Changes in GDP}

The performance of GDP-linked bonds (as measured by the total return index) is one of the most important investment criteria while the cash flow structure is an important issue for the assessment of the liquidity needs of investors and issuing countries. To shed light on the pricing mechanism and on payment structure for GDP-linked bonds the sensitivities of these bond prices and of the cash flows are investigated using simulations based on different artificially generated GDP developments.

Such a simulation has two advantages. Firstly, the influence of all possible GDPscenarios can be analysed. Secondly, the influence of external factors (such as contagion effects or rumours on capital markets) can be eliminated.

The simulation is constructed as follows. The instrument of reference is a bond with a clean price of 100 and with a zero-default probability. Based on this bond, all kinds of GDP-linked bonds are constructed for typical GDP processes (upward sloping, downward sloping or flat). Finally, surprising GDP changes (shocks) between the date of issuance and maturity are incorporated into the simulation.

\section{Analysis of cash flow sensitivities}

The major aim of this analysis is to find out under which circumstances a country benefits from issuing a GDP-linked bond (called BONDs in the remainder of this section). This examination is supplemented by an exemplary look at an existing bond.

Three results in particular are worthy of note. Firstly, the value of the initial coupon of the different BONDs crucially depends on long term GDP expectations: if market participants expect GDP to rise, initial coupons are very low (where low means lower than the coupon of a straight bond). This effect is stronger for option-free BONDs $(2,6)$ and is weak - but still exists - for the BONDs to be redeemed at par $(1,5)$. This phenomenon can be traced back to the expectations of rising coupons (and of a probable redemption over par) in the future. In this context it is important to remember that the initial coupons are determined in such a manner that the issuing prices of all BONDs equal the issuing price of the straight bond (which equals 100). For the same reasons the initial coupons are very high in the case of falling GDP expectations. If the market expects GDP to remain stable over the time 
period to maturity, initial coupons of BONDs are generally equal to the coupons of straight bonds.

Secondly, in the case of shocks, the payment structure changes as expected: positive shocks lead to an increase in coupons and/or repayment and vice versa. The sensitivity is especially high for those BONDs that are linked to the GDP growth rate $(4,8)$.

Thirdly, the payments of GDP-linked bonds that are directly linked to the development of GDP do not necessarily conform with the business cycle of the issuing country. This means that, in the case of a downturn, payments are probably still high and vice versa. In contrast, BONDs that are linked to the growth rate of GDP $(4,8)$ do not necessarily conform with the paying ability of the issuing country, i.e. payment duties might be high due to a short term GDP upswing while in fact the GDP decreased since the date of issuance. Additionally, due to the high sensitivity of growth rate-linked BONDs, there is a danger of undesirable procyclical effects due to a long publication lag of GDP and, particularly if the determination of payments is based on year-to-year data, this lag might lead to a situation in which payments are still high while in fact the economic circumstances have already deteriorated.

Example: Analysis of a bond issued by Indonesia 88-93 (SIN: 485500)

The examination of GDP-linked bonds constructed on the basis of an existing bonds issued by Indonesia supports the significance of the conclusions drawn from the simulations. The underlying data for the following verbal description can be found in appendix 7.1.

Investors expect a positive GDP-development at the date of issuance which is signalled by a positive drift component $\mu(0.06)$. During the time to maturity the actual GDP and the GDP expectations improve further ( $\mu$ is rising from 0.06 to 0.071 between Oct. 1988 and Oct. 1993). Due to the favourable initial GDP expectations the initial coupons (especially of BONDs 2, 3, 6, 7) are very low. The improving GDP-expectations give rise to a more than expected increase of the coupon during the time to maturity. This, in turn, leads to a higher total payment to BOND investors compared to investors of the straight bond.

The relative differences between the payments for the single BOND-variants and the payments for the common Indonesian straight bond are also consistent with the simulations above. While the BONDs that are redeemed at par $(1,5)$ have only slightly higher total payments, the total cash flows of the BONDs 
that fully participate in the GDP-development $(2,6)$ and those that have a floor at par for the repayment $(3,7)$ are distinctly higher.

A comparison of the actual time structure of the payments and the GDP of Indonesia reveals that the country can fulfil its payment duties in accordance with its paying ability (i.e. the coupons are rising and the GDP is rising contemporaneously). However, the time structure of payments is not in accordance with the business cycle of Indonesia. This becomes obvious especially in the case of the BONDs 2, 3, 6, 7, where the coupons increase over time but - despite a favourable GDP development - always remain below the coupon of the straight bond.

In that example, no major differences between the BONDs that are linked to the quarter-to-quarter development of the $\operatorname{GDP}(4,8)$ and the similarly designed BONDS that are linked to the absolute GDP $(1,5)$ are observable. The main reason for that is that there were no major shocks between issuing date and time to maturity. ${ }^{15}$

\section{Analysis of the performance sensitivities}

One important result of the simulations is that, without any shocks, all BONDs and the straight bond have the same total return. This holds because the yield to maturity (promised yield) is the same for both types of bonds under examination the straight bond and the BOND. Thus, in our simulation, no premium is added to the yields of BONDs which could be due to lack of liquidity, lack of publicity, higher cash flow uncertainty etc.

If shocks to GDP are applied, however, the results are no longer quite so straightforward. In general, BONDs outperform straight bonds if there is a surprising increase in GDP, and underperform straight bonds if GDP declines unexpectedly. This is due to the changing cash flows of BONDs after the shock and the accompanying enhancement / degradation of the effective yield. Furthermore it can be seen that the bigger the leverage on the amount of cash still to be paid out after the shock, the more the BONDs react to that shock. This means that usually option-free BONDs $(2,6)$ exhibit the highest sensitivity, because all future payments (coupon and redemption) are affected by the GDP-change to the full extent. They are followed by BONDs with a floor on the redemption value at par $(3,7)$. BONDs that are necessarily redeemed at par $(1,5)$ usually show the weakest reaction among the bonds that are linked to the direct development of the GDP.

15 Other examples that are constructed based on existing government bonds (see table 2), however, reveal the differences in the cash flow structure between these two types of bonds. These calculations are available upon request from the authors. 
A more detailed analysis of the performance of GDP-linked bonds under different GDP-scenarios can be found below:

\section{Expectation of an upward sloping GDP:}

- All GDP-linked bonds have lower initial coupons than the straight bonds, which is a result of the expectations of high future payments. However the coupons of these BONDs that are redeemed at par $(1,4,5,8)$ are only slightly lower than those of the straight bonds. As a result, they do not react very strongly on GDP shocks. The other BONDs have very low initial coupons. However, there is virtually no difference between BONDs with a floor on the repayment at par (3, 7) and BONDs of which the repayment fully participates in the GDP development $(2,6)$. This is the case because under the expectation of an upward sloping GDP the probability of redemption below par is very low.

- Only in the case of a surprisingly (very) strong decrease of GDP, BONDs with a floor on repayment $(3,7)$ benefit and show a superior performance compared to the other BONDs.

- Due to the low initial coupons, BONDs face a high risk of yield changes under the scenario of positive GDP-expectations. This is due to the relatively high amount of cash to be paid out closed to maturity (similar to the duration, which is also higher for bonds with high cash flows to be paid at the end of the time to maturity ${ }^{16}$ ).

Expectation of a downward sloping GDP:

- All BOND-coupons are higher than the coupons of the straight bonds, which is a result of the lower expected future payments. The initial coupons of BONDs with a floor $(3,7)$ and those that are redeemed at par $(1,4,5,8)$ are of similar amount and only slightly higher than the straight bonds' coupons. However, the initial coupons of BONDs that fully participate in the development of the GDP $(2,6)$ are much higher.

- In case of a sudden increase of the GDP, BONDs with a floor $(3,7)$ show a semistrong reaction while BONDs that fully participate in the GDP development (2, 6 ) exhibit a very strong reaction. BONDs that are redeemed at par could not benefit much from that development since the repayment is already fixed; they show only weak reactions.

- In case of a sudden decline of the GDP, BONDs that fully participate in the GDP development $(2,6)$ show the strongest reaction. BONDs that are redeemed at par

\footnotetext{
16 See Fabozzi (2001), p. 128.
} 
and BONDS with a floor $(1,3,5,7)$ do not react very strongly since their expected repayment does not change.

- All BONDs exhibit lower sensitivities than in the case of positive GDP expectations. The reason for that is the relatively high initial coupon that leaves a relatively smaller fraction of cash - which is the component that mostly determines the change in the performance of BONDs - for the time after a shock.

\section{Expectation of a flat GDP:}

- The initial coupons of all BONDs and the original straight bonds are quite similar. Therefore, the main driver of the sensitivity is the final repayment.

- In case of a surprising rise of the GDP, BONDs that fully participate in the GDP development and BONDs with a floor $(2,3,6,7)$ react both positively and almost to the same extent. BONDS that are redeemed at par $(1,5)$ do not show much of a reaction.

- In case of a surprising decrease of the GDP, BONDs that fully participate in the GDP development $(2,6)$ show a noticeable negative reaction while BONDs with a floor and BONDS that are redeemed at par $(1,3,5,7)$ do not react distinctly.

Independent of the type of expectation, BONDs that are linked to the quarter-toquarter development of GDP $(4,8)$ react stronger than similar designed BONDs that are linked to the absolute GDP $(1,5)$. The longer the shock takes, the higher the differences in the performance sensitivities. However, no explicit statements regarding their performance relative to option-free GDP-linked bonds and those with a redemption floor at par can be made. The higher sensitivities of the BONDs 4 and 8 give rise to a higher ex ante uncertainty about the future cash flows. This, in turn, might imply that the forecasting of these cash flows is more complicated and, therefore, investors might possibly demand a higher risk premium for this type of bonds.

The statements above apply independently of the time to maturity of the respective bonds. However, it has to be considered that, the longer the time to maturity after a GDP-shock, the stronger the BONDs react. This holds because of the relatively higher fraction of cash that is affected by the shock. Several shocks during the time to maturity result in an overlapping of the effects described above. In case of the existence of several shocks, no explicit statements can be made regarding the performance of BONDs that are linked to the GDP growth rate $(4,8)$ relative to the similar designed BONDs that are linked to the absolute GDP $(1,5)$. This is due to the fact that the performance of BONDs 4 and 8 does not only depend on the change of the GDP but also of the length and intensity of the single shocks. 


\subsection{Analysis of the Simulated GDP-linked Bond Prices}

In this section we provide a largely verbal description of the most important results of further analyses we performed based on the simulated GDP-linked bond prices. The according tables can be found in the appendix 7.2-7.5.

\section{Performance comparisons and correlations}

The total return indices of the simulated GDP-linked bond prices are compared with the government bonds which served as the basis of the simulations. In addition, the behaviour of the simulated bond prices is compared with three international bond indices from JP Morgan: a global index, a European index and an index of Brady bonds.

In sum, the results of the performance comparison (as measured by the Sharpe ratio) show that out- or underperformance of the GDP-linked bonds depends strongly on the country chosen. But, depending on the time period, outperformance or underperformance may occur even in the same country. With regard to returns, there does not appear to be a preferable type of GDP-linked bonds which has always or in most cases a better performance than the other types. Tables A1 to A8 in appendix 7.2 show the mean, the standard deviation and the Sharpe ratio for different bonds from different issuer countries.

The returns (= logarithmic differential to the month before) for all the types of GDPlinked bonds taken into account correlate highly with the returns on the underlying straight bond. Most correlations are in the range between 0.7 and 0.99. Only in few cases the correlations fall short of 0.7. Similar results hold for the correlations between the returns of GDP-linked bonds and the Brady bond-index. This leads to the conclusion that GDP-linked bonds and Brady bonds can be considered as relatively close substitutes. The results of the correlation analysis are shown in tables A9 to A16 (appendix 7.3).

To draw more accurate conclusions about the relationship between GDP-linked bonds and straight bonds, a regression analysis of the returns of both types of bonds is performed:

$$
r_{\text {Bond }}=\alpha+\beta \cdot r_{\text {StraightBond }}+\varepsilon
$$

with $r_{\text {Bond }}$ being the log-return of the GDP-linked bond and $r_{\text {StraightBond }}$ being the logreturn of the underlying government bond. In this equation, the intercept $\alpha$ is a measure of how the returns of both types of bonds are significantly different. A significantly positive $\alpha$, for example, means that the returns of GDP-linked bonds are significantly higher than the returns of the straight bonds. 
As a result of the estimations, about half of the regressions show a significant $\alpha$; almost all of them are positive. Contrary, all negative estimations (except two) are not significant. This gives rise to the suggestion that GDP-linked bonds might be a reasonable alternative to straight bonds. The results of the regressions also show that especially the GDP-linked bond variants BOND 5 and BOND 8 outperform the straight bonds. Both bonds have in common that the redemption payment is at par and that payment is partly guaranteed. This might indicate that the choice of how to link the coupon payments to the GDP (linkage to the GDP development or, instead, linkage to the quarter-to-quarter change) is not of major importance regarding the out- or underperformance. It is also worth noting that the generally high values for $R^{2}$ of the regressions emphasise the validity of the correlation analyses.

Although the regressions showed that GDP-linked bonds can sometimes outperform straight bonds, the main result of the analyses is that the GDP-linked bond and the underlying straight bond are relatively close substitutes. The detailed results of the regression analysis can be found in tables A17 to A24 (appendix 7.4).

\section{$\underline{\text { Hurdle rates and risk premiums }}$}

Finally, we try to answer the central question: when and under which circumstances are investors willing to invest in GDP-linked bonds rather than in straight bonds? We address this issue by analysing whether GDP-linked bonds have higher chances to be included into an international bond portfolio compared to straight bonds.

We use a method of portfolio optimisation in the Markowitz mean-variance framework. ${ }^{17}$ This method prescribes that the existence of an optimum requires the following equation to hold:

$$
\frac{\bar{R}_{B}-r}{\sigma_{B}}>\frac{\bar{R}_{P}-r}{\sigma_{P}} \cdot \rho_{B, P}
$$

with $\bar{R}_{B}, \bar{R}_{P}$ :average log-return of the bond $B$ or the bond portfolio $P$; $\sigma_{B}, \sigma_{P}$ : standard deviation of the log-returns of the bond $B$ or the portfolio $P$; $r$ : risk free rate and $\rho_{B, P}$ :correlation of the log-returns of the bond $B$ and the portfolio $P$.

Consequently the expected minimum rate of return $E\left(R_{\text {Min }}\right)$ for inclusion into the portfolio of a bond is calculated as:

Hurdle rate: $E\left(R_{\text {Min }}\right)=E\left(R_{P}-r\right) \cdot \frac{\sigma_{B}}{\sigma_{P}} \cdot \rho_{B, P}+E(r)$

17 The proceeding is described in more detail in Elton/Gruber (1991). 
This means that when the bond $B$ has an expected return that is slightly higher than $E\left(R_{M i n}\right)$ the bond will be included into portfolio $P$ with a positive weight.

For the expected return of the bond portfolio and of the risk free rate we use the average values of the sample period. The difference between the hurdle rates of the existing government bond and the corresponding GDP-linked bond can be regarded as the maximum additional risk premium that an investor can accept when he decides to include the GDP-linked bond into the bond portfolio.

For all three bond indices under examination, the results show that the hurdle rates for the GDP-linked bonds do not deviate much from the hurdle rates of the straight bonds. However, in some cases the GDP-linked bonds even have to have negative risk premiums to be competitive with the straight bond. A comparison of the maximally acceptable risk premiums with risk premiums calculated from correlations between world GDP and the GDP of different developing countries (calculated by Borensztein and Mauro) ${ }^{18}$ reveals that there are at least some types of GDP-linked bonds that are competitive with straight bonds i.e. GDP-linked bonds that could bear a relatively high additional risk premium.

An important general conclusion can be drawn based on these results: GDP-linked bonds might be chosen by investors if the GDP of the issuing country has a negative or low positive correlation with the GDP of the reference region of the investor. If the investor holds an internationally well diversified bond portfolio, the correlations with world GDP are relevant. The calculations of Borensztein/Mauro show ${ }^{19}$ : these correlations proved to be negative for Bangladesh, Egypt, India, Pakistan, Syria, Vietnam and one or two other countries. The risk premium for these countries might even be negative compared with straight bonds. Thus, from this point of view, such countries are possible candidates for the first issues of GDP-linked bonds. The results of the analysis of hurdle rates and risk premiums are provided in tables A25 to A32 (appendix 7.5).

To sum up, from the perspective of an investor GDP-linked bonds are neither generally better nor worse than straight bonds. To improve the possibilities for the successful introduction of GDP-linked bonds on international capital markets, the GDP of the candidate countries should exhibit a negative correlation to the GDP of the reference region of the investor.

\footnotetext{
18 See Borensztein/Mauro (2002), table 1b p. 13.

${ }^{19}$ See Borensztein/Mauro (2002), tables $1 b$ and 1c, pp. 13-14.
} 


\subsection{Conclusions on the Empirical Analyses}

The results from the empirical analysis show that GDP-linked bonds can act as alternative investment vehicles compared to straight bonds. As the different types of GDP-linked bonds considered in this study have different characteristics, the question remains which type of GDP-linked bond should be chosen by the issuing country.

Types of GDP-linked bonds which depend on the development of GDP during time to maturity (BOND1-3 and BOND5-7) exhibit a gradual increase in payments over time when expected GDP rises. If redemption is also linked to GDP, payment at maturity may exceed par value by a very large amount. Although this pattern accords with an increasing ability to pay, if investors are to accept such patterns of payment they must have great confidence in the future state of a country's economy and its willingness to pay. These types of GDP-linked bonds are therefore only suitable for countries with a low probability of default and a correspondingly high rating. The lower the rating, the shorter should be the time to maturity.

If, in contrast, only the coupon payments are linked to the development of GDP (BOND1 and 5), the time to maturity may be longer as redemption will be at par value. In this case, payments are also linked to the ability to pay. If the time to maturity is relatively long, payments will only respond slightly to business cycle variations and will move in accordance with expected medium and long term growth. If the aim is to link coupon payments to business cycle changes, the coupon should be linked to quarter-to-quarter changes in GDP (BOND 4 and 8). This type of GDP-linked bonds reduces the risk of the issuing country becoming insolvent during recessions.

The rather portfolio oriented part of the analysis shows that the returns for all the types of GDP-linked bonds taken into account correlate highly with the returns on the underlying straight bond. A regression analysis also provides evidence that GDP-linked bonds can be seen as a close substitute to the underlying straight bonds. Finally, using a portfolio optimisation approach in the Markowitz mean-variance framework, it can be shown that international investors will not accept high risk premiums when they think about including the GDP-linked bond into an international bond portfolio.

An important general conclusion can be drawn from the latter result: GDP-linked bonds might be chosen by investors if the GDP of the issuing country has a negative or low positive correlation with the GDP of the reference region of the investor. If the investor holds an internationally well diversified bond portfolio, the correlations with world GDP are relevant. 


\section{Regulatory assessment}

\subsection{Introduction}

There would be no need for extensive regulation to cover the issue of GDP-linked bonds which are not covered by any form of public guarantee as it would be up to markets to decide on the success of this innovation. A public guarantee (e.g. given by the World Bank), however, even though it may be beneficial for capital market access, must be classified as government intervention and as such needs further justification. The benefits of a partial guarantee are straightforward: it can attract certain groups of investors (such as insurance companies or pension funds) to invest in low-rated issuing countries' GDP-linked bonds that would otherwise not invest in these instruments. This, in turn, increases the probability that the country faces a satisfactory capital supply from a broad investor base. However, such guarantees do not automatically conduce to a successful bond issue. These guarantees always have to be regarded in the light of the possible negative incentives the issuing countries face. In this context, the most important question is: Does a partial public guarantee boost a moral-hazard problem between issuers and investors?

\subsection{Experience with World Bank Guarantees}

Experiences with bond related World Bank guarantees exist in the context of socalled Policy Based Guarantees (PBG). These guarantees have been granted in recent years in relation to bonds issued by Argentina ${ }^{20}$ and Colombia ${ }^{21}$. The objective of the PBG programme was to safeguard capital market access for countries with a promising policy record. ${ }^{22}$ The two PBG constructions have been designed as rolling guarantees covering only the most immediate payment obligations. Although the guarantees successfully simplified the issuance of the bonds, the scheme's reputation has been damaged by the subsequent Argentinean default. When Argentina defaulted on its World Bank guaranteed bond in October 2002, investors were compensated by the World Bank. However, as Argentina failed to compensate the World Bank for its guarantee payment within the prescribed deadline, the rolling over of the guarantee to the next payment stopped and the country defaulted on subsequent payments without receiving any privileged treatment this time round. This experience has damaged market confidence in the value of this type of rolling World Bank guarantee and also led to a rating downgrade of the similarly designed Colombian bond. ${ }^{23}$ If, therefore, GDP-linked

\footnotetext{
20 See World Bank (2000).

21 See World Bank (2001).

22 See World Bank (2002).

23 See Moody's (2002).
} 
bonds are to be enhanced by a World Bank guarantee, the PBG can no longer be applied in its current, unmodified form.

\subsection{Guarantees, GDP-linked Bonds and Capital Market Access}

Experience with debut bond placements shows that the following factors are crucial for market access: a favourable global situation in terms of high growth and low interest rates, promising macroeconomic development in the candidate country and a rating which, as a rule, should not be lower than BB. Debut bonds are normally constructed in a standardised way as fixed coupon bonds, typically with a five year maturity and without any enhancements. Minimum volumes are \$250 million and in most cases $\$ 500$ million or more. The issues are mostly denominated in euros or US-dollars. ${ }^{24}$

On the basis of this experience it would appear that a World Bank guarantee is not necessarily helpful for a country's first issue. The disadvantage of a (partially) guaranteed first bond is that it is of little use as a benchmark for future unguaranteed issues. The establishment of a benchmark, however, is one of the most important aims of a debut placement in order to reduce information asymmetries for future issues. The guarantee also complicates pricing which is always a delicate task for a debut placement. Furthermore, the inclusion of such a guarantee could possibly signal that the issuer country has a low degree of creditworthiness which, in turn, might dramatically reduce the chances of a successful issue. It should be noted here, that the weight of the latter argument has probably risen dramatically after the experience with the Argentine case.

The lessons for the suitability of GDP-linked bonds as debut bonds are ambiguous. On the one hand, a favourable growth perspective which is critical for market access is at the same time particularly helpful as a sales argument in the case of GDP-linked bonds. On the other hand the GDP-linked bond's unusual construction complicates pricing which could be a serious disadvantage for a debut bond.

\subsection{GDP-linked Bonds and Moral Hazard}

Moral hazard describes the risk that one party to a contract can change its behaviour to the detriment of the other party once the contract has been concluded. In the case of (partially) guaranteed GDP-linked bonds especially two moral hazard problems arise. First, 'creditor moral hazard' means that creditors could be encouraged to incautiously lend funds to the issuer country. Second, 'debtor moral hazard' can occur if the economic policy of the issuer country deteriorates as a result of the simplified capital access due to the guarantee.

${ }^{24}$ See Gelos et al. (2003), IMF (2003). 
The possible link between IMF guarantees respectively World Bank guarantees and the behaviour of creditors and debtors has been intensively discussed in the reform debate of the Bretton-Woods institutions. ${ }^{25}$ The empirical evidence with regard to both creditor and debtor moral hazard is mixed. Regarding the creditor moral hazard, there are indications that, at least temporarily, the perception of implicit IMF guarantees might lead to a narrowing of the interest rate spreads of emerging countries. Such a narrowing can be - but does not have to be necessarily - seen as result of the decreasing cautiousness of investors.

Moral hazards risks appear to be of minor relevance as far as partially guaranteed GDP-linked bonds are concerned. Nevertheless, a differentiated view on the problem of a creditor moral hazard is necessary. The encouragement of investors with a guarantee to buy GDP-linked bonds is not automatically problematic since it is the central goal of this construction. However, it is necessary that investors always perform their own reasonable assessment of the countries paying ability and willingness. That is typically the case if investors bear a big part of the financial detriment in case of a default. In this context it can be assumed that, as long as the explicit guarantee is only partial and private investors suffer losses exceeding 50 per cent of their capital in the event of default, there remain strong incentives for a careful risk analysis on the side of investors.

With a GDP-linked bond, debtor moral hazard is a theoretical possibility not only with a guarantee, but also without since low growth reduces the debt service due to the GDP-linked yield. Whether debtor moral hazard is also of practical relevance is highly questionable as long as GDP-linked issues constitute only a minor part of a country's debt. And even in this case, the substantial political costs of low growth will tend to outweigh any incentives for low growth. Moreover, countries that initially enter the capital market with such a financial instrument have strong incentives to present itself as a reliable and reputable creditor in order to ease the future access to capital market financing.

A specific type of debtor moral hazard in the context of GDP-linked bonds refers to the possible downside manipulation of national accounting data. ${ }^{26}$ This problem, however, does not seem to be of major importance, neither. Politicians rather have strong incentives to present overly positive national accounting data for a number of reasons (e.g. to become re-elected, to build up reputation). Additionally, in order to ensure investor confidence in the quality of such yield-determining data, there is the possibility that a GDP-linked bond issuing country subscribes to the IMF's "Special Data Dissemination Standard" which defines certain statistical standards and

25 See Solow (1982), Schuknecht (1996), Zhang (1999), Lane/Philips (2000), Dell'Ariccia/ Schnabel/Zettelmeyer (2002), Kamin (2002), Dreher (2003).

26 See Borensztein/Mauro (2002). 
includes monitoring by IMF staff. A list of countries that have subscribed to the standards can be found on the IMF website. ${ }^{27}$

\subsection{Extent and Burden of Guarantee}

A few calculations can help to assess the possible burden on a guarantor. On the basis of the link between rating classes and default probabilities it is possible to derive the guarantee ratios which are necessary to improve the rating of a country. This calculation proceeds as follows: In a first step, the expected capital loss $E(C L)$ of a high-rated bond (superscript $H$ ) is expressed as the product of the probability of default $D$ and the loss given default which is a result of the recovery rate of this rating class $r$.

$$
E\left(C L^{H}\right)=P\left(D^{H}\right) *\left(1-r^{H}\right)
$$

Analogously, the expected loss of a low rated bond (superscript $L$ ) with a guarantee ratio $g$ provided by a default free organisation can be expressed as:

$$
E\left(C L^{L}\right)=P\left(D^{L}\right) *\left(1-r^{L}-g\right)
$$

Finally, the guarantee ratio that leads to the equality of both expectation values $\left(\mathrm{g}^{*}\right)$ is calculated by:

$$
g^{*}=1-r^{L}-\frac{P\left(D^{H}\right)}{P\left(D^{L}\right)} *\left(1-r^{H}\right)
$$

Table 3 shows the results of the calculations and provides an overview of guarantee ratios necessary to lift up the rating for different rating classes. The results show that guarantee ratios between 15 and 30 per cent can lift a bond by one rating subcategory - e.g. from $\mathrm{B} 1$ to $\mathrm{Ba} 2$. In order to lift a non-investment-grade bond into investment grade, investors would need guarantees covering between 25 and 50 per cent of capital in the case of a BB-bond.

${ }^{27}$ See http://dsbb.imf.org/Applications/web/sddscountrylist/ 
Table 3: Guarantee ratios necessary to change rating classes

\begin{tabular}{|c|c|c|c|c|c|c|c|c|c|c|}
\hline & & \multicolumn{3}{|c|}{ Investment Grade } & \multicolumn{6}{|c|}{ Non Investment Grade } \\
\hline & & to Baal & to $\mathrm{Baa} 2$ & to $\mathrm{Baa} 3$ & to $\mathrm{Bal}$ & to $\mathrm{Ba} 2$ & to $\mathrm{Ba} 3$ & to $\mathrm{B} 1$ & to $\mathrm{B} 2$ & to $\mathrm{B} 3$ \\
\hline \multirow{6}{*}{ 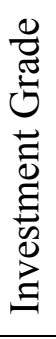 } & from & $0 \%$ & & & & & & & & \\
\hline & Baa1 & & & & & & & & & \\
\hline & from & $16 \%$ & $0 \%$ & & & & & & & \\
\hline & Baa2 & & & & & & & & & \\
\hline & from & $36 \%$ & $27 \%$ & $0 \%$ & & & & & & \\
\hline & Baas & & & & & & & & & \\
\hline \multirow{10}{*}{ 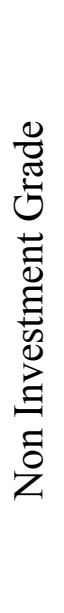 } & from & $44 \%$ & $39 \%$ & $25 \%$ & $0 \%$ & & & & & \\
\hline & Ba1 & & & & & & & & & \\
\hline & from & $47 \%$ & $43 \%$ & $32 \%$ & $13 \%$ & $0 \%$ & & & & \\
\hline & $\mathrm{Ba} 2$ & & & & & & & & & \\
\hline & from & $52 \%$ & $51 \%$ & $46 \%$ & $37 \%$ & $31 \%$ & $0 \%$ & & & \\
\hline & $\mathrm{Ba} 3$ & & & & & & & & & \\
\hline & from B1 & $58 \%$ & $57 \%$ & $53 \%$ & $47 \%$ & $42 \%$ & $19 \%$ & $0 \%$ & & \\
\hline & from B2 & $59 \%$ & $58 \%$ & $55 \%$ & $50 \%$ & $46 \%$ & $27 \%$ & $12 \%$ & $0 \%$ & \\
\hline & from B3 & $60 \%$ & $59 \%$ & $57 \%$ & $53 \%$ & $50 \%$ & $37 \%$ & $25 \%$ & $16 \%$ & $0 \%$ \\
\hline & from & $86 \%$ & $85 \%$ & $84 \%$ & $81 \%$ & $79 \%$ & $69 \%$ & $61 \%$ & $54 \%$ & $42 \%$ \\
\hline
\end{tabular}

Data: Moody’s Investors Service (2004). Recovery rates correspond to the „senior unsecured issuer-weighted mean recovery rates 1982-2003“ with rating class clustering 5 years before default. Default probabilities correspond to ,average global cumulative issuer-weighted default rates $1983-2003$ “ for a 5-year period.

A direct impact of World Bank guarantees for a number of GDP-linked bonds on national budgets can be excluded. So far the World Bank has always worked profitably due to its successful risk management and its role as a de facto preferred creditor. As long as guarantees in favour of GDP-linked bonds are not accompanied by deteriorating standards in creditworthiness checks and risk management, a direct negative impact on World Bank's owners is not realistic. Nevertheless, some calculations indicate that - depending on the rating class of the issuer - the World Bank would implicitly subsidise a guarantee. This can be shown by comparing the income from guarantee fees with the expected losses of the guarantor associated with defaults. Figure 1 summarizes the results of these calculations and indicates that - given its present level of guarantee fees - the World Bank is implicitly subsidizing guarantees in favour of non-investment-grade countries. 
Figure 1: Present value of an expected gain (+) / loss (-) from granting a 5-year guarantee

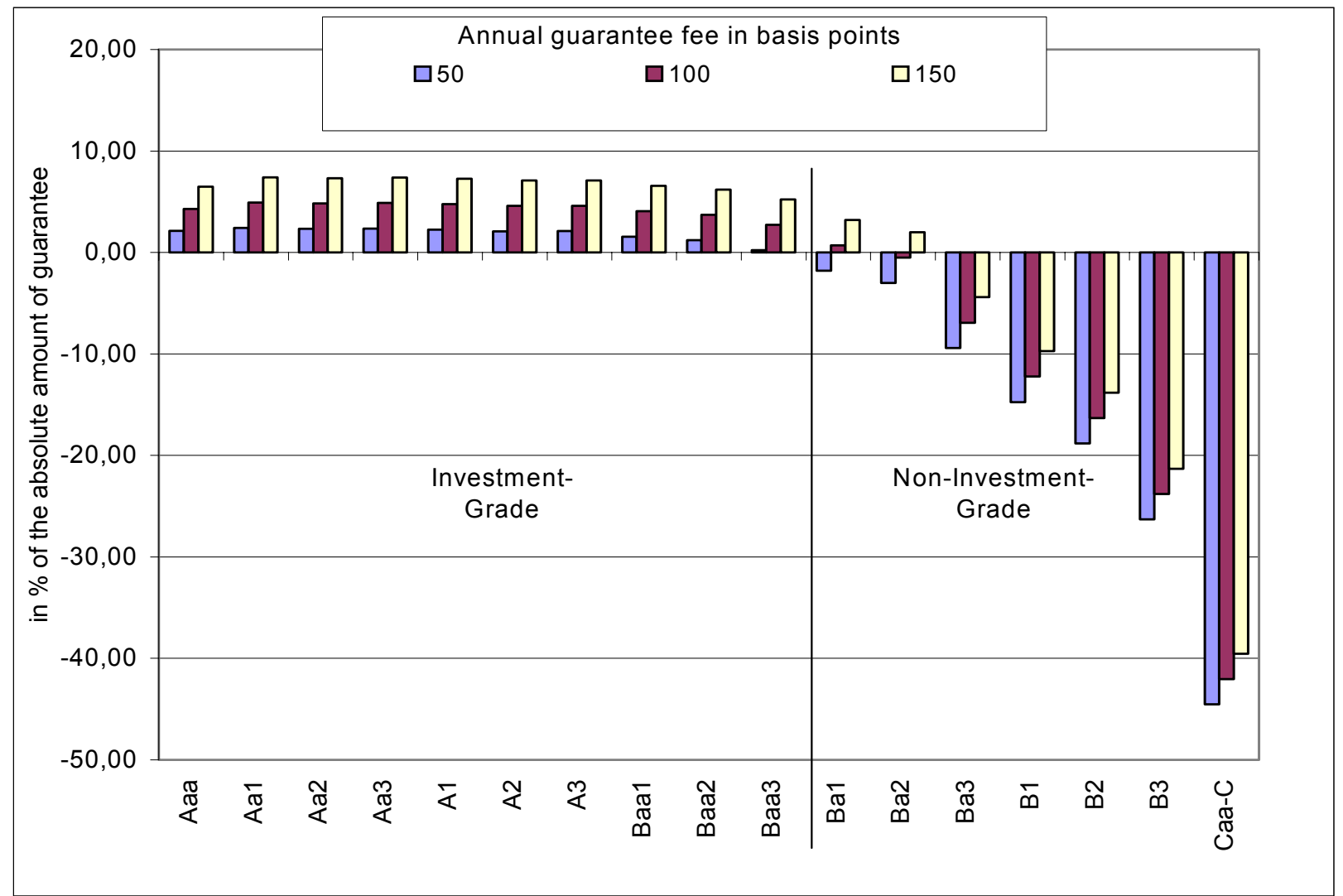

The default and recovery rates correspond to the average values of corporate bonds, worldwide, for the period 1983-2003 (Moody's Investors Service, 2004).

\subsection{Country Selection}

From the point of view of public guarantees, candidates for GDP-linked bonds have to exhibit some desirable characteristics. First, a rating is indispensable as it is the country's subscription to the IMF's Special Data Dissemination Standard. Second, countries lacking the creditworthiness required for eligibility for World Bank credits are too far off from capital market access to be GDP-linked bond candidates.

Table 4 provides an overview of selected countries that are eligible for World Bank credits. 
Table 4: Selected countries that are eligible for World Bank credits and their ratings

\begin{tabular}{|c|c|c|}
\hline \multicolumn{3}{|c|}{ Per capita income 2936-5115 USD } \\
\hline Croatia & (Baa3, BBB-) & 4640 \\
\hline \multicolumn{3}{|c|}{ Per capita income 1416-2935 USD } \\
\hline Turkey & $(\mathrm{B} 1, \mathrm{~B}+)$ & 2500 \\
\hline Russia & $(\mathrm{Baa} 3, \mathrm{BB}+)$ & 2140 \\
\hline Romania & $(\mathrm{Ba3}, \mathrm{BB})$ & 1850 \\
\hline Bulgaria & $(\mathrm{Ba} 2, \mathrm{BB}+)$ & 1790 \\
\hline Macedonia & N.A. & 1700 \\
\hline Kasakhstan & $(\mathrm{Baa} 3, \mathrm{BB}+)$ & 1510 \\
\hline \multicolumn{3}{|c|}{ Per capita income $735-1415$ USD } \\
\hline Belarus & N.A. & 1360 \\
\hline Turkmenistan & $(\mathrm{B} 2, \ldots)$ & 1200 \\
\hline Ukraine & $(\mathrm{B} 1, \mathrm{~B})$ & 770 \\
\hline
\end{tabular}

Date of eligibilty of World Bank credits: July 2003, World Bank (2003); in brackets: Foreign Currency Rating (Moody's, Standard \& Poor's), date of the rating: February 2004, right column = per capita income in USD.

\subsection{Conclusions on the Role of Guarantees}

The idea of a GDP-linked bond is in no sense conditional on a public guarantee although partial guarantees might be appealing for certain risk-averse investor groups. The most serious counter-argument against partially guaranteed GDP-linked bonds results from the difficulties of debut bond issues. Due to information and pricing problems investors have a preference for conventional ('plain vanilla') bonds when a country offers its first issue. GDP-linked bonds as such have a handicap in this situation which would even be aggravated by a guarantee. Moral hazard problems are only a minor concern in this case.

In spite of these problems, it may be worth considering a partial guarantee if a country is within close reach of capital market access. Any guarantee scheme applied in the context of GDP-linked bonds should have a much simpler approach compared to the recent Policy Based Guarantees favouring bonds from Argentina and Colombia. 
The limited involvement of the World Bank in this context would accord with the Meltzer Report, for example, which recommends that the Bank should change from a capital intensive creditor into a catalyst of private resource flows. ${ }^{28}$

\section{General Conclusions}

- What are the special characteristics of GDP-linked Bonds?

Debt service payments are linked to the paying ability of the issuing country.

- Which factor should be used to link these bonds to economic development?

○ GDP is preferable (high correlation with ability to pay).

○ Commodity prices if highly correlated with GDP.

- What are the pros and cons of GDP-linked bonds s compared to conventional bonds?

o Pros:

- Payments of the bond are linked to short- or long-term solvency.

- Transfer of business cycle or growth risk from the issuing country to the investor.

○ Cons:

- Risk transfer has to be rewarded by risk premium.

- New capital market instrument which induces an additional risk premium (e.g. due to unknown price behaviour and liquidity risk).

- Who are potential investors? Institutional investors, in particular, emerging market bond funds, hedge funds, insurance companies, pension funds.

- Which are the basic types of GDP-linked bonds?

○ Linkage of coupon and/or redemption payment to GDP development (i.e. GDP relative to the GDP in the year of issuance).

o Linkage of the coupon to GDP growth (e.g., year-on-year or quarter-toquarter growth).

- What are the additional features of GDP-linked bonds?

○ Option on coupon to guarantee that the coupon does not become negative.

○ Option on redemption payment to guarantee redemption at least at par.

${ }^{28}$ See IFIAC, 2000 
o Combination with a partial guarantee of the payments by e.g. an international organization.

- Is a pro-cyclical effect on debt service payments possible? Yes, a procyclical change of coupon and/or redemption payments is possible. However, it depends on the publication lag and the GDP data frequency. The danger of a pro-cyclical effect is low for quarterly data, but relatively high for yearly data.

- Should reporting of national account data be controlled by international organizations? Yes, the reliability of national account data is essential to build-up confidence. Therefore, it is indispensable that the issuing country subscribes to the IMF's Special Data Dissemination Standard which defines standards and implies IMF staff monitoring.

- How to cope with GDP revision? GDP-linked bonds should be based on revised and definite GDP data and not on the first reported GDP figures. This increases the publication lag but reduces incentives to misreport i.e. understate GDP systematically.

\section{- Which countries should issue GDP-linked bonds?}

- The GDP of the issuing country should have a low positive or even a negative correlation with worldwide GDP. This reduces the risk premium which investors demand as compensation for bearing GDP risk.

- The issuer country should profit from the structure of the payments of GDP-linked bonds and the specific form of risk transfer. GDP-linked bonds are particularly interesting for countries expected to have temporary solvency problems in the future.

- First-time issuers are at a disadvantage because both the country and the financial instrument are relatively unfamiliar on capital markets.

- Is a partial public guarantee an important element of a GDP-linked bonds? Under which circumstances?

○ On the one hand, any guarantee complicates pricing and reduces the bond's usefulness as a country benchmark.

- On the other hand, a partial guarantee probably helps to balance the interests of investors (in terms of the risk-return relation) and the paying ability of the issuer country.

- A partial guarantee may, however, be worth being considered for a country which is not far away from market access or which finds itself in a difficult global market environment. 
- Which type of GDP-linked bonds is the best one?

o Very short time to maturity (e.g. 3 years): Linkage of coupon and redemption payments to GDP development might be suitable, possibly combined with an option to guarantee redemption not below par.

o Longer time to maturity (more than $3-5$ years): Redemption at par. Otherwise the redemption payment could be far above (or below) par. Coupon could be either linked to GDP development (i.e. relative to GDP at date of issuance) or to GDP growth (e.g. quarter-to-quarter change).

- What are the basic conditions for a successful GDP-linked bond issue?

○ GDP-linked bonds should have a simple structure (easy to understand and to price) if they are to be accepted by the capital market.

- High total volume of issues to guarantee a liquid secondary market (at least 500 million euros or US dollars).

- A carefully prepared pioneer GDP-linked bonds issue should be launched. If successful, this prototype would facilitate subsequent issue by other countries.

- What are additional conditions for a successful issue?

○ A favourable macroeconomic situation of the issuer country and the world economy.

- A stable track record of the issuer country in political and economic terms (could be partially substituted by a public guarantee).

o The existence of a rating.

- Subscription of the issuer country to the IMF's Special Data Dissemination Standard.

- Countries which are not eligible for World Bank credits are definitely not GDP-linked bond candidates. 


\section{References}

Bafin, 2001, Verordnung über die Anlage des gebundenen Vermögens in Versicherungsunternehmen (Anlageverordnung - AnlV), 20.12.2001.

Bailey, N., 1983, A Safety Net for Foreign Lending, Business Week, January 10.

Borensztein, E./Mauro, P., 2002, Reviving the Case for GDP-Indexed Bonds, IMF Policy Discussion Paper, PDP/02/10.

Borensztein, E./Mauro, P., 2004, The case for GDP-indexed bonds, Economic Policy, vol. 19 (38), pp. 165-216.

Brynjolfsson, J./Fabozzi, F.J. 1999, Handbook of Inflation Indexed Bonds, New Hope, Pennsylvania

Caballero, R., 2002, Coping with Chile's External Vulnerability: A Financial Problem, Working Paper.

Dell'Ariccia, Giovanni, Schnabel, Isabel und Jeromin Zettelmeyer (2002), Moral Hazard and International Crisis Lending: A Test, IMF Working Paper WP/02/181, Washington.

Dreher, Axel (2003), Die Kreditvergabe von IWF und Weltbank, Ursachen und Wirkungen aus politisch-öonomischer Sicht, Berlin.

Drèze, J.H., 2000, Globalisation and Securitisation of Risk Bearing, Université Catholique de Louvain, Belgium, Working Paper

Elton, E.J./Gruber, M.J., (1991), International Diversification from a Swiss Perspective, Finanzmarkt und Portfolio Management, 5. Jahrgang, Nr. 2, S. 120-129.

Fabozzi, F.J., 2001, The Handbook of Fixed Income Securities, $6^{\text {th }}$ edition, New York.

Financial Times (2004), IMF mulls radical proposal on debt: Growth-Indexed Bonds, August 10, 2004, London Edition.

Gelos, R. Gaston, Sahay, Ratna and Guido Sandleris (2003), Sovereign Borrowing by Developing Countries: What Determines Market Access?, IMF Working Paper, October 2003, http://www.imf.org/external/np/res/seminars/2003/lic/pdf/gg.pdf

Haldane, A., 1999, Private Sector Involvement in Financial Crisis: Analytics and Public Policy Approaches, Financial Stability Review, Issue 7, pp. 184-202.

IFIAC, International Financial Institution Advisory Commission (2000), "Meltzer Report", Final Report, March 1999, http://www.house.gov/jec/imf/imfpage.htm . 
International Monetary Fund (2003), Access to International Capital Markets for First-Time Sovereign Issuers, Prepared by the International Capital Market Department, November 17, 2003.

Kamin, Teven B. (2002), Identifying the Role of Moral Hazard in International Financial Markets, Board of Governors of the Federal Reserve System, International Finance Discussion Papers, Number 736, Washington.

Korn, Sebastian and Susanne Kruse (2004), Einfache Verfahren zur Bewertung von inflationsgekoppelten Finanzprodukten, Notes of the German Society for Insurance and Financial Mathematics (Blätter der DGVFM), XXVI (3), 35167, May.

Lane, Timothy and Steven Phillips (2000), Does IMF Financing Result in Moral Hazard?, IMF Working Paper WP/00/168, Washington.

Moody's Investors Service (2002), Moody's lowers rating of $9.75 \%$ notes of the Republic of Colombia to Ba2, Global Credit Research Rating Action, 18 Oct 2002.

Moody's Investors Service (2004), Default \& Recovery Rates of Corporate Bond Issuers, Special Comment, January 2004.

Newey, W.K./West K.D. (1987), A Simple Positive Semi-Definite Heterskedasticity and Autocorrelation Consistent Covariance Matrix, Econometrica 55, 703708 .

Price, R., 1997, The Rationale and Design of Inflation-indexed Bonds, Washington DC, IMF-Working paper series no. 97/12.

Schuknecht, Ludger (1996), Political Business Cycles and Fiscal Policies in Developing Countries, Kyklos, 49 (2), pp. 155-170.

Shiller, R.J., 1993, Macro Markets: Creating Institutions for Managing Society's Largest Economic Risks, Oxford.

Solow, Robert (1982), On the Lender of Last Resort, in: Kindleberger, C. and J.P. Laffargue (Hrsg.): Financial Crises: Theory, History and Policy, Cambridge University Press, Cambridge.

Standard \& Poor's (2003), Ratings Performance 2002, Default, Transition, Recovery and Spreads.

World Bank (2000), Argentian Introduces Novel Offerings, Project Finance and Guarantees, January 2000, Washington.

World Bank (2001), Colombia Ensures Financing for 2001 with Support from the World Bank under a Policy Based Guarantee, Project Finance and Guarantees, September 2001, Washington. 
World Bank (2002), The World Bank Guarantees, Leveraging Private Finance for Emerging Markets, Washington.

World Bank (2003), World Bank Annual Report, Vol. 1, Year in Review, Washington.

Zhang, Xiaoming Alan (1999), Testing for 'Moral Hazard' in Emerging Markets Lending, Institute of International Finance Research Paper, No. 99-1, Washington. 


\section{Appendix}

\subsection{Cash Flow Sensitivities of a Simulated GDP-linked Bond for Indonesia}

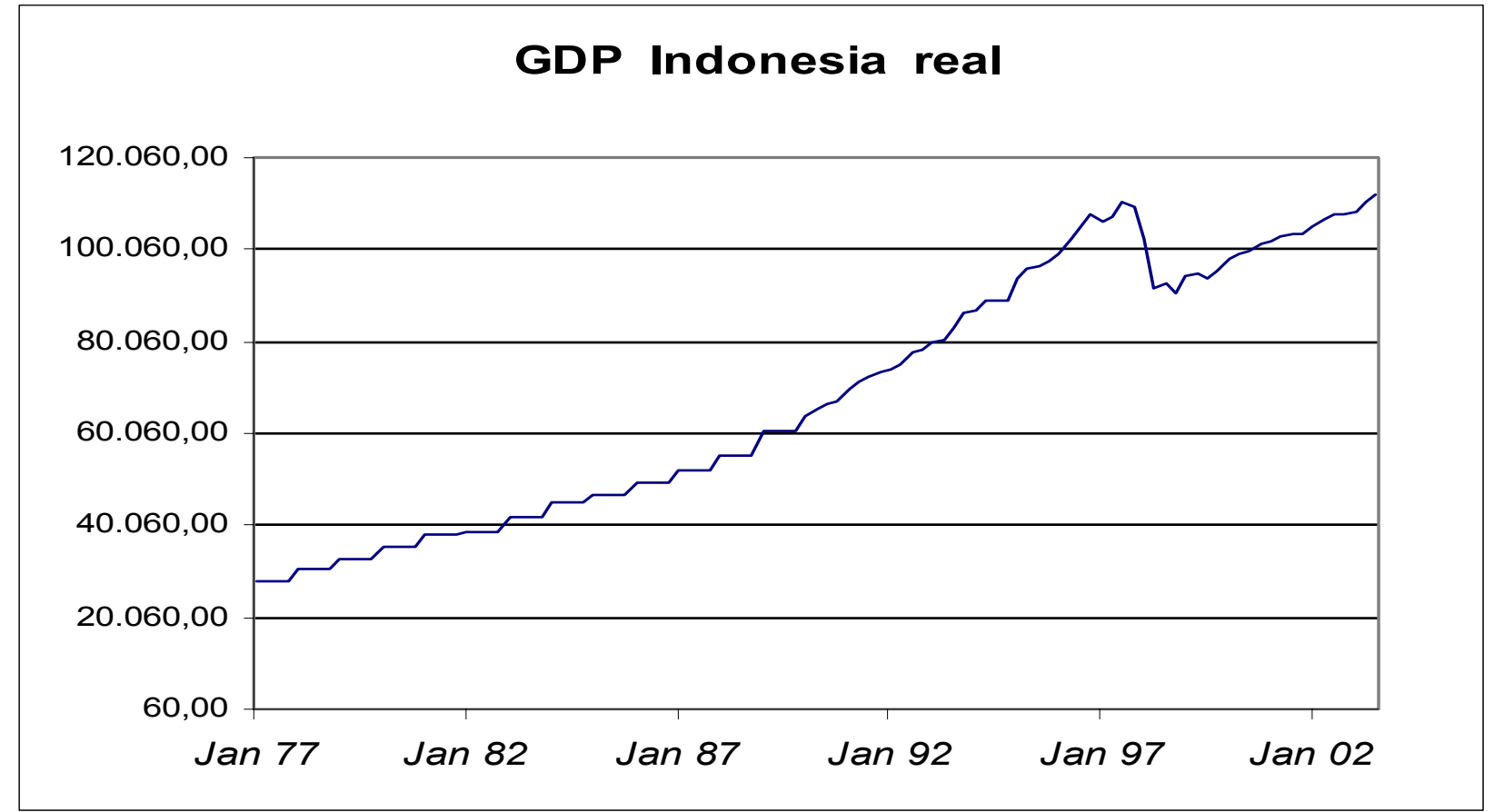

\begin{tabular}{|r|r|r|}
\hline \multicolumn{3}{|c|}{ Indonesia } \\
\hline & \multicolumn{1}{|c|}{ Drift } & \multicolumn{1}{|c|}{ Volatility } \\
\hline Oct. 88 & 0.060 & 0.011 \\
\hline Jan. 89 & 0.060 & 0.011 \\
\hline Apr. 89 & 0.060 & 0.011 \\
\hline Jul. 89 & 0.061 & 0.011 \\
\hline Oct. 89 & 0.061 & 0.011 \\
\hline Jan. 90 & 0.062 & 0.012 \\
\hline Apr. 90 & 0.066 & 0.018 \\
\hline Jul. 90 & 0.066 & 0.018 \\
\hline Oct. 90 & 0.065 & 0.018 \\
\hline Jan. 91 & 0.064 & 0.018 \\
\hline Apr. 91 & 0.066 & 0.019 \\
\hline Jul. 91 & 0.066 & 0.019 \\
\hline Oct. 91 & 0.066 & 0.019 \\
\hline Jan. 92 & 0.065 & 0.019 \\
\hline Apr. 92 & 0.066 & 0.019 \\
\hline Jul. 92 & 0.067 & 0.018 \\
\hline Oct. 92 & 0.070 & 0.019 \\
\hline Jan. 93 & 0.070 & 0.018 \\
\hline Apr. 93 & 0.070 & 0.018 \\
\hline Jul. 93 & 0.069 & 0.019 \\
\hline Oct. 93 & 0.071 & 0.019 \\
\hline
\end{tabular}

Note: volatility affects the drift 


\section{Cash flows Indonesia}

SIN:

485500

Date of redemption: Oct. 93

Date of issue:

Oct 88

GDP at time of Emission: $\quad 55352$

World Bank guarantee: $70 \%$

\begin{tabular}{|c|c|c|c|c|c|c|c|}
\hline \multicolumn{2}{|c|}{$\begin{array}{l}\text { GDP Growth } \\
\text { GDP }\end{array}$} & $\begin{array}{l}2.17 \% \\
60380.3\end{array}$ & $\begin{array}{l}1.00 \% \\
65831.6\end{array}$ & $\begin{array}{l}1.34 \% \\
71634.8\end{array}$ & $\begin{array}{l}3.48 \% \\
75902\end{array}$ & $\begin{array}{l}3.39 \% \\
81335\end{array}$ & \\
\hline $\begin{array}{l}\text { Cash } \\
\text { Flow }\end{array}$ & $\begin{array}{c}\text { Initial } \\
\text { Coupon }\end{array}$ & Oct 89 & Oct 90 & Oct 91 & Oct 92 & Oct 93 & Sum \\
\hline BOND 1 & $5,33 \%$ & 5,81 & 6,34 & 6,90 & 7,31 & 107,83 & 134,18 \\
\hline BOND 2 & $0,10 \%$ & 0,11 & 0,12 & 0,13 & 0,14 & 147,09 & 147,59 \\
\hline BOND 3 & $0,10 \%$ & 0,11 & 0,12 & 0,13 & 0,14 & 147,09 & 147,59 \\
\hline BOND 4 & $6,39 \%$ & 7,04 & 5,87 & 6,21 & 8,34 & 108,25 & 135,71 \\
\hline BOND 5 & $5,27 \%$ & 5,75 & 6,27 & 6,82 & 7,23 & 107,74 & 133,80 \\
\hline BOND 6 & $0,04 \%$ & 0,05 & 0,05 & 0,05 & 0,06 & 147,00 & 147,21 \\
\hline BOND 7 & $0,04 \%$ & 0,05 & 0,05 & 0,05 & 0,06 & 147,00 & 147,21 \\
\hline BOND 8 & $6,32 \%$ & 6,97 & 5,80 & 6,13 & 8,27 & 108,18 & 135,36 \\
\hline $\begin{array}{l}\text { Existing } \\
\text { Bond }\end{array}$ & $6,38 \%$ & 6,38 & 6,38 & 6,38 & 6,38 & 106,38 & 131,88 \\
\hline
\end{tabular}

\subsection{Distribution Characteristics of the Total Returns of the Simulated GDP-linked Bonds}

The GDP-linked bonds which we examined reveal the following characteristics:

- BOND1: Coupon linked to GDP development (i.e. relative to GDP at date of issuance), redemption at par $(=100)$.

- BOND2: Coupon and redemption linked to GDP development (i.e. relative to GDP at date of issuance).

- BOND3: Coupon and redemption linked to GDP development (i.e. relative to GDP at date of issuance). In addition call option to guarantee redemption which is at least at par.

- BOND4: Coupon linked to GDP growth (i.e. quarter-to-quarter change of GDP), redemption at par. 
- BOND5 - BOND8: as above BOND1 - BOND4, but combined with a partial public guarantee $(70 \%)$ of the redemption payment.

The three international bond indices that serve as a comparison benchmark are total return indices (denominated in euro). The indices are disclosed by JP Morgan. Total returns are calculated for the time between issuance and redemption of the compared bonds. The three indices are:

- JP Global: global government bonds of industrial countries (comprises the 20 biggest international bond-markets)

- JP Europe: European government bonds (comprises the 14 biggest european bond-markets)

- JP EMBI+ Brady: government bonds of emerging markets (only Brady Bonds), comprises 14 countries.

The calculations are based on annualised log-returns, expressed as a percentage value:

$=12 \cdot\left[\log \left(\right.\right.$ TotalReturn $\left._{t}\right)-\log \left(\right.$ TotalReturn $\left.\left._{t-1}\right)\right] \cdot 100$.

The Sharpe ratio $=$ average risk adjusted return $=(\mu-r) / \sigma$. Numerator $=$ mean of log-returns $(\mu)$ minus the risk free rate $(r)$. Denominator $=$ measure of risk $=$ standard deviation $(\sigma)$.

A higher Sharpe ratio indicates that an investment is more favourable for an investor since it yields a higher net return for a given unit of risk.

Risk free rate $=3$-month interest rate Europe. For periods before the introduction of the euro, an equally-weighted average of the 3-month interest rate in Germany, France and Italy is applied. Since the introduction of the euro, the 3-months-Euribor is applied. 
Table A-1: Brasil (SIN: 614414), Period: 2/2001-12/2002 (23 observations) Log-returns are annualised and expressed in percentages.

\begin{tabular}{|l|c|c|c|c|}
\hline & $\begin{array}{c}\text { Guarantee } \\
\text { (Yes/No) }\end{array}$ & Mean & $\begin{array}{c}\text { Standard } \\
\text { deviation }\end{array}$ & Sharpe Ratio \\
\hline Existing bond & -- & $-14,74$ & 184,49 & $-0,100$ \\
\hline BOND 1 & No & $-15,98$ & 184,17 & $-0,107$ \\
\hline BOND 2 & No & $-15,95$ & 184,52 & $-0,106$ \\
\hline BOND 3 & No & $-18,01$ & 184,17 & $-0,118$ \\
\hline BOND 4 & No & $-15,15$ & 185,08 & $-0,102$ \\
\hline BOND 5 & Yes & $-3,56$ & 68,89 & $-0,105$ \\
\hline BOND 6 & Yes & $-5,40$ & 67,29 & $-0,135$ \\
\hline BOND 7 & Yes & $-5,40$ & 67,29 & $-0,135$ \\
\hline BOND 8 & Yes & $-3,35$ & 69,32 & $-0,101$ \\
\hline JP Global & -- & 2,66 & 14,55 & $-0,069$ \\
\hline JP Europe & -- & 7,05 & 11,75 & 0,288 \\
\hline JP EMBI+ Brady & -- & 5,44 & 61,92 & 0,029 \\
\hline
\end{tabular}

Table A-2: Brasil (SIN: 607749), Period: 9/2000-12/2002 (28 observations) Log-returns are annualised and expressed in percentages.

\begin{tabular}{|l|c|c|c|c|}
\hline & $\begin{array}{c}\text { Guarantee } \\
\text { (Yes/No) }\end{array}$ & Mean & $\begin{array}{c}\text { Standard } \\
\text { deviation }\end{array}$ & Sharpe Ratio \\
\hline Existing bond & -- & 2,42 & 157,59 & $-0,010$ \\
\hline BOND 1 & No & 2,35 & 157,02 & $-0,010$ \\
\hline BOND 2 & No & $-0,05$ & 158,99 & $-0,025$ \\
\hline BOND 3 & No & $-0,07$ & 159,01 & $-0,025$ \\
\hline BOND 4 & No & 3,09 & 154,91 & $-0,005$ \\
\hline BOND 5 & Yes & 5,55 & 45,27 & 0,037 \\
\hline BOND 6 & Yes & 3,61 & 47,15 & $-0,005$ \\
\hline BOND 7 & Yes & 3,60 & 47,14 & $-0,006$ \\
\hline BOND 8 & Yes & 5,38 & 44,67 & 0,034 \\
\hline JP Global & -- & 2,49 & 20,27 & $-0,068$ \\
\hline JP Europe & -- & 7,39 & 10,78 & 0,327 \\
\hline JP EMBI+ Brady & -- & 4,84 & 58,76 & 0,017 \\
\hline
\end{tabular}


Table A-3: Indonesia (SIN: 485500), Period: 1/1989-9/1993 (57 observations) Log-returns are annualised and expressed in percentages.

\begin{tabular}{|l|c|c|c|c|}
\hline & $\begin{array}{c}\text { Guarantee } \\
\text { (Yes/No) }\end{array}$ & Mean & $\begin{array}{c}\text { Standard } \\
\text { deviation }\end{array}$ & Sharpe Ratio \\
\hline Existing bond & -- & 6,43 & 12,66 & $-0,227$ \\
\hline BOND 1 & No & 7,14 & 13,10 & $-0,165$ \\
\hline BOND 2 & No & 8,29 & 16,91 & $-0,059$ \\
\hline BOND 3 & No & 8,27 & 16,93 & $-0,060$ \\
\hline BOND 4 & No & 7,52 & 13,04 & $-0,136$ \\
\hline BOND 5 & Yes & 6,96 & 9,96 & $-0,234$ \\
\hline BOND 6 & Yes & 8,12 & 14,93 & $-0,079$ \\
\hline BOND 7 & Yes & 8,12 & 14,93 & $-0,079$ \\
\hline BOND 8 & Yes & 7,04 & 9,37 & $-0,241$ \\
\hline JP Global & -- & 8,38 & 30,28 & $-0,03$ \\
\hline JP Europe & -- & 8,18 & 13,71 & $-0,082$ \\
\hline JP EMBI+ Brady & -- & -- & -- & -- \\
\hline
\end{tabular}

Table A-4: Mexico (SIN: 402280), Period: 10/1992-2/1996 (41 observations) Log-returns are annualised and expressed in percentages.

\begin{tabular}{|l|c|c|c|c|}
\hline & $\begin{array}{c}\text { Guarantee } \\
\text { (Yes/No) }\end{array}$ & Mean & $\begin{array}{c}\text { Standard } \\
\text { deviation }\end{array}$ & Sharpe Ratio \\
\hline Existing bond & -- & 9,26 & 11,06 & 0,169 \\
\hline BOND 1 & No & 10,00 & 11,70 & 0,225 \\
\hline BOND 2 & No & 8,42 & 17,24 & 0,060 \\
\hline BOND 3 & No & 8,41 & 17,23 & 0,060 \\
\hline BOND 4 & No & 11,45 & 15,36 & 0,265 \\
\hline BOND 5 & Yes & 8,76 & 8,09 & 0,170 \\
\hline BOND 6 & Yes & 7,38 & 15,44 & 0,00 \\
\hline BOND 7 & Yes & 7,37 & 15,43 & 0,00 \\
\hline BOND 8 & Yes & 9,34 & 9,98 & 0,197 \\
\hline JP Global & -- & 7,27 & 25,85 & $-0,004$ \\
\hline JP Europe & -- & 8,50 & 18,57 & 0,060 \\
\hline JP EMBI+ Brady & -- & 13,81 & 76,86 & 0,084 \\
\hline
\end{tabular}


Table A-5: Mexico (SIN: 130890), Period: 5/1996-12/2002 (80 observations) Log-returns are annualised and expressed percentages.

\begin{tabular}{|l|c|c|c|c|}
\hline & $\begin{array}{c}\text { Guarantee } \\
\text { (Yes/No) }\end{array}$ & Mean & $\begin{array}{c}\text { Standard } \\
\text { deviation }\end{array}$ & Sharpe Ratio \\
\hline Existing bond & -- & 8,98 & 36,26 & 0,139 \\
\hline BOND 1 & No & 10,65 & 36,98 & 0,181 \\
\hline BOND 2 & No & 12,64 & 39,11 & 0,223 \\
\hline BOND 3 & No & 11,54 & 37,93 & 0,200 \\
\hline BOND 4 & No & 10,69 & 37,88 & 0,178 \\
\hline BOND 5 & Yes & 8,54 & 18,64 & 0,247 \\
\hline BOND 6 & Yes & 9,93 & 22,09 & 0,272 \\
\hline BOND 7 & Yes & 9,80 & 21,93 & 0,267 \\
\hline BOND 8 & Yes & 8,27 & 18,76 & 0,231 \\
\hline JP Global & -- & 8,39 & 20,40 & 0,218 \\
\hline JP Europe & -- & 8,02 & 12,84 & 0,318 \\
\hline JP EMBI+ Brady & -- & 15,60 & 72,75 & 0,160 \\
\hline
\end{tabular}

Table A-6: Turkey (SIN: 485678), Period: 1/1989-9/1995 (81 observations) Log-returns are annualised and expressed in percentages.

\begin{tabular}{|l|c|c|c|c|}
\hline & $\begin{array}{c}\text { Guarantee } \\
\text { (Yes/No) }\end{array}$ & Mean & $\begin{array}{c}\text { Standard } \\
\text { deviation }\end{array}$ & Sharpe Ratio \\
\hline Existing bond & -- & 7,27 & 28,98 & $-0,043$ \\
\hline BOND 1 & No & 7,49 & 29,20 & $-0,035$ \\
\hline BOND 2 & No & 6,97 & 30,86 & $-0,050$ \\
\hline BOND 3 & No & 6,55 & 30,89 & $-0,064$ \\
\hline BOND 4 & No & 7,63 & 31,56 & $-0,028$ \\
\hline BOND 5 & Yes & 7,00 & 16,92 & $-0,089$ \\
\hline BOND 6 & Yes & 6,23 & 21,58 & $-0,106$ \\
\hline BOND 7 & Yes & 6,23 & 21,58 & $-0,106$ \\
\hline BOND 8 & Yes & 6,89 & 19,77 & $-0,082$ \\
\hline JP Global & -- & 6,21 & 28,87 & $-0,080$ \\
\hline JP Europe & -- & 7,08 & 16,05 & $-0,089$ \\
\hline JP EMBI+ Brady & -- & -- & -- & -- \\
\hline
\end{tabular}


Table A-7: Turkey (SIN: 129180), Period: 1/1996-7/1998 (31 observations) Log-returns are annualised and expressed in percentages.

\begin{tabular}{|l|c|c|c|c|}
\hline & $\begin{array}{c}\text { Guarantee } \\
\text { (Yes/No) }\end{array}$ & Mean & $\begin{array}{c}\text { Standard } \\
\text { deviation }\end{array}$ & Sharpe Ratio \\
\hline Existing bond & -- & 6,15 & 6,13 & 0,246 \\
\hline BOND 1 & No & 7,14 & 6,20 & 0,403 \\
\hline BOND 2 & No & 12,23 & 12,28 & 0,618 \\
\hline BOND 3 & No & 10,31 & 7,24 & 0,782 \\
\hline BOND 4 & No & 6,93 & 7,03 & 0,325 \\
\hline BOND 5 & Yes & 5,56 & 3,72 & 0,246 \\
\hline BOND 6 & Yes & 9,19 & 5,34 & 0,851 \\
\hline BOND 7 & Yes & 9,01 & 5,26 & 0,830 \\
\hline BOND 8 & Yes & 5,45 & 4,29 & 0,186 \\
\hline JP Global & -- & 12,14 & 21,36 & 0,351 \\
\hline JP Europe & -- & 12,63 & 14,74 & 0,542 \\
\hline JP EMBI+ Brady & -- & 25,86 & 69,63 & 0,305 \\
\hline
\end{tabular}

Table A-8: Venezuela (SIN: 411810), Period: 2/1994-9/2000 (80 observations) Log-returns are annualised and expressed in percentages.

\begin{tabular}{|l|c|c|c|c|}
\hline & $\begin{array}{c}\text { Guarantee } \\
\text { (Yes/No) }\end{array}$ & Mean & $\begin{array}{c}\text { Standard } \\
\text { deviation }\end{array}$ & Sharpe Ratio \\
\hline Existing bond & -- & 7,78 & 47,87 & 0,062 \\
\hline BOND 1 & No & 7,56 & 48,25 & 0,057 \\
\hline BOND 2 & No & 5,32 & 48,68 & 0,010 \\
\hline BOND 3 & No & 5,31 & 48,59 & 0,010 \\
\hline BOND 4 & No & 7,07 & 46,66 & 0,048 \\
\hline BOND 5 & Yes & 6,24 & 20,12 & 0,070 \\
\hline BOND 6 & Yes & 4,14 & 24,03 & $-0,029$ \\
\hline BOND 7 & Yes & 4,14 & 23,86 & $-0,029$ \\
\hline BOND 8 & Yes & 5,39 & 19,43 & 0,029 \\
\hline JP Global & -- & 8,24 & 22,57 & 0,151 \\
\hline JP Europe & -- & 7,34 & 16,85 & 0,149 \\
\hline JP EMBI+ Brady & -- & 14,40 & 81,41 & 0,118 \\
\hline
\end{tabular}




\subsection{Correlations of GDP-linked Bonds with Existing Bonds and Bond}

\section{Indices}

The following table shows the correlations between the Total-Return-Indices of the eight simulated GDP-linked Bonds and their respective government bonds as well as the three international bond indices from JP Morgan (JP1 = JP Global, JP2 = JP Europe, JP3 = JP EMBI+ Brady). Correlations are carried out using data measured in log-returns.

Table A-9: Brasil (SIN: 614414), Period: 2/2001-12/2002 (23 Observations)

Log-Returns are annualised and expressed in percentages.

\begin{tabular}{|l|c|c|c|c|}
\hline & Bond & JP1 & JP2 & JP3 \\
\hline Bond & 1 & $-0,04$ & $-0,44$ & 0,81 \\
\hline BOND 1 & 0,99 & $-0,04$ & $-0,44$ & 0,80 \\
\hline BOND 2 & 0,99 & $-0,05$ & $-0,44$ & 0,79 \\
\hline BOND 3 & 0,99 & $-0,06$ & $-0,44$ & 0,79 \\
\hline BOND 4 & 0,99 & $-0,06$ & $-0,47$ & 0,80 \\
\hline BOND 5 & 0,98 & 0,01 & $-0,32$ & 0,79 \\
\hline BOND 6 & 0,96 & $-0,02$ & $-0,32$ & 0,75 \\
\hline BOND 7 & 0,96 & $-0,02$ & $-0,32$ & 0,75 \\
\hline BOND 8 & 0,98 & $-0,01$ & $-0,38$ & 0,80 \\
\hline
\end{tabular}

Table A-10: Brasil (SIN: 607749), Period: 9/2000-12/2002 (28 Observations)

Log-Returns are annualised and expressed in percentages

\begin{tabular}{|l|c|c|c|c|}
\hline & Bond & JP1 & JP2 & JP3 \\
\hline Bond & 1 & 0,04 & $-0,33$ & 0,74 \\
\hline BOND 1 & 0,99 & 0,04 & $-0,33$ & 0,74 \\
\hline BOND 2 & 0,99 & 0,03 & $-0,34$ & 0,73 \\
\hline BOND 3 & 0,99 & 0,03 & $-0,34$ & 0,73 \\
\hline BOND 4 & 0,99 & 0,04 & $-0,34$ & 0,74 \\
\hline BOND 5 & 0,97 & 0,07 & $-0,24$ & 0,71 \\
\hline BOND 6 & 0,97 & 0,04 & $-0,25$ & 0,69 \\
\hline BOND 7 & 0,97 & 0,04 & $-0,25$ & 0,69 \\
\hline BOND 8 & 0,97 & 0,08 & $-0,25$ & 0,72 \\
\hline
\end{tabular}


Table A-11: Indonesia (SIN: 485500), Period: 1/1989-9/1993 (57 Observations) Log-Returns are annualised and expressed in percentages.

\begin{tabular}{|l|c|c|c|}
\hline & Bond & JP1 & JP2 \\
\hline Bond & 1 & 0,38 & 0,43 \\
\hline BOND 1 & 0,98 & 0,39 & 0,44 \\
\hline BOND 2 & 0,85 & 0,37 & 0,40 \\
\hline BOND 3 & 0,85 & 0,37 & 0,40 \\
\hline BOND 4 & 0,93 & 0,37 & 0,39 \\
\hline BOND 5 & 0,87 & 0,35 & 0,55 \\
\hline BOND 6 & 0,72 & 0,32 & 0,44 \\
\hline BOND 7 & 0,72 & 0,32 & 0,44 \\
\hline BOND 8 & 0,83 & 0,33 & 0,51 \\
\hline
\end{tabular}

Table A-12: Mexico (SIN: 402280), Period: 10/1992-2/1996 (80 Observations) Log-Returns are annualised and expressed in percentages.

\begin{tabular}{|c|c|c|c|c|}
\hline & Bond & JP1 & JP2 & JP3 \\
\hline Bond & 1 & 0,27 & 0,28 & 0,41 \\
\hline BOND 1 & 0,96 & 0,19 & 0,20 & 0,28 \\
\hline BOND 2 & 0,69 & 0,05 & 0,04 & 0,04 \\
\hline BOND 3 & 0,69 & 0,05 & 0,04 & 0,04 \\
\hline BOND 4 & 0,78 & 0,12 & 0,13 & 0,20 \\
\hline BOND 5 & 0,86 & 0,27 & 0,24 & 0,26 \\
\hline BOND 6 & 0,51 & 0,05 & 0,02 & $-0,04$ \\
\hline BOND 7 & 0,51 & 0,05 & 0,02 & $-0,04$ \\
\hline BOND 8 & 0,75 & 0,24 & 0,22 & 0,26 \\
\hline
\end{tabular}


Table A-13: Mexico (SIN: 130890), Period: 5/1996-12/2002 (80 Observations)

Log-Returns are annualised and expressed in percentages.

\begin{tabular}{|c|c|c|c|c|}
\hline & Bond & JP1 & JP2 & JP3 \\
\hline Bond & 1 & 0,01 & 0,03 & 0,71 \\
\hline BOND 1 & 0,99 & 0,03 & 0,04 & 0,71 \\
\hline BOND 2 & 0,95 & 0,08 & 0,08 & 0,68 \\
\hline BOND 3 & 0,98 & 0,08 & 0,09 & 0,70 \\
\hline BOND 4 & 0,98 & 0,02 & 0,02 & 0,69 \\
\hline BOND 5 & 0,95 & 0,13 & 0,22 & 0,67 \\
\hline BOND 6 & 0,90 & 0,19 & 0,24 & 0,64 \\
\hline BOND 7 & 0,90 & 0,19 & 0,24 & 0,65 \\
\hline BOND 8 & 0,93 & 0,10 & 0,17 & 0,65 \\
\hline
\end{tabular}

Table A-14: Turkey (SIN: 485678), Period: 1/1989-9/1995 (81 Observations) Log-Returns are annualised and expressed in percentages.

\begin{tabular}{|l|c|c|c|}
\hline & Bond & JP1 & JP2 \\
\hline Bond & 1 & 0,18 & 0,10 \\
\hline BOND 1 & 0,99 & 0,19 & 0,12 \\
\hline BOND 2 & 0,89 & 0,26 & 0,22 \\
\hline BOND 3 & 0,89 & 0,24 & 0,22 \\
\hline BOND 4 & 0,91 & 0,22 & 0,11 \\
\hline BOND 5 & 0,92 & 0,26 & 0,27 \\
\hline BOND 6 & 0,67 & 0,30 & 0,36 \\
\hline BOND 7 & 0,67 & 0,30 & 0,36 \\
\hline BOND 8 & 0,76 & 0,30 & 0,23 \\
\hline
\end{tabular}


Table A-15: Turkey (SIN: 129180), Period: 1/1996-7/1998 (31 Observations)

Log-Returns are annualised and expressed in percentages.

\begin{tabular}{|l|c|c|c|c|}
\hline & Bond & JP1 & JP2 & JP3 \\
\hline Bond & 1 & 0,42 & 0,45 & 0,56 \\
\hline BOND 1 & 0,96 & 0,35 & 0,37 & 0,55 \\
\hline BOND 2 & 0,45 & 0,36 & 0,38 & 0,58 \\
\hline BOND 3 & 0,90 & 0,33 & 0,38 & 0,51 \\
\hline BOND 4 & 0,86 & 0,16 & 0,16 & 0,37 \\
\hline BOND 5 & 0,76 & 0,45 & 0,53 & 0,64 \\
\hline BOND 6 & 0,67 & 0,34 & 0,44 & 0,52 \\
\hline BOND 7 & 0,68 & 0,34 & 0,73 & 0,52 \\
\hline BOND 8 & 0,67 & 0,15 & 0,20 & 0,39 \\
\hline
\end{tabular}

Table A-16: Venezuela (SIN: 411810), Period: 2/1994-9/2000 (80 Observations)

Log-Returns are annualised and expressed in percentages.

\begin{tabular}{|l|c|c|c|c|}
\hline & Bond & JP1 & JP2 & JP3 \\
\hline Bond & 1 & $-0,07$ & $-0,03$ & 0,51 \\
\hline BOND 1 & 0,99 & $-0,07$ & $-0,03$ & 0,52 \\
\hline BOND 2 & 0,97 & $-0,04$ & $-0,01$ & 0,54 \\
\hline BOND 3 & 0,97 & $-0,05$ & $-0,01$ & 0,54 \\
\hline BOND 4 & 0,97 & $-0,05$ & $-0,03$ & 0,50 \\
\hline BOND 5 & 0,94 & 0,05 & 0,15 & 0,56 \\
\hline BOND 6 & 0,84 & 0,07 & 0,16 & 0,56 \\
\hline BOND 7 & 0,84 & 0,07 & 0,16 & 0,56 \\
\hline BOND 8 & 0,82 & 0,10 & 0,16 & 0,51 \\
\hline
\end{tabular}

\subsection{Performance Comparison between GDP-linked Bonds and Existing Bonds}

The performance comparison is based on the regression equation $r_{\text {Bond }}=\alpha+\beta \cdot r_{\text {StraightBond }}+\varepsilon$, where the log-returns of total return-index of a GDPlinked bond $\left(=r_{\text {Bond }}\right)$ are regressed on a constant as well as on the log-returns of the total return-index of respective government bonds $\left(=r_{\text {StraightBond }}\right)$, which had been used in simulating the eight GDP-linked bonds. 
In this model the significant constant $\alpha$ measures how much the log-returns of the respective GDP-linked bonds deviate on average from the log-returns of the current government bonds. The determination of standard errors was adjusted using the method von Newey and West (1987) in order to deal with possible autocorrelation and heteroscedasticity.

For each of the estimated parameters the p-value (which can be found in brackets) is generated under the hypothesis that the parameter is equal to zero, meaning that is has no significant influence on the dependent variable. Since the $p$-values reveal implicitly the probability of wrongly rejecting the hypothesis they can be directly compared with the commonly used levels of significance (e.g. $10 \%, 5 \%, 1 \%$ ). A parameter is significant when the p-value is smaller than the selected probability of wrongly rejecting the hypothesis. Significant $\alpha$ values are marked $* * *$, or *** if the parameters derived in the sample are significant at a $10 \%, 5 \%$ or resp. $1 \%$ level. The estimators for $\beta$ are in all cases significant at a $1 \%$ level, but we chose not to mark them distinctively to preserve ease of reading.

Table A-17: Estimators and p-values: Brasil (SIN: 614414), Period: 2/2001-12/2002

\begin{tabular}{|l|l|l|l|}
\hline Bond & $\alpha$ & $\beta$ & $R^{2}$ \\
\hline BOND 1 & $-1,27(0,39)$ & $0,99(0,00)$ & 0,99 \\
\hline BOND 2 & $-1,32(0,79)$ & $0,99(0,00)$ & 0,98 \\
\hline BOND 3 & $-3,37(0,44)$ & $0,99(0,00)$ & 0,99 \\
\hline BOND 4 & $-0,38(0,85)$ & $1,00(0,00)$ & 0,99 \\
\hline BOND 5 & $1,82(0,56)$ & $0,37(0,00)$ & 0,96 \\
\hline BOND 6 & $-0,26(0,95)$ & $0,35(0,00)$ & 0,91 \\
\hline BOND 7 & $-0,26(0,95)$ & $0,35(0,00)$ & 0,91 \\
\hline BOND 8 & $2,12(0,40)$ & $0,37(0,00)$ & 0,97 \\
\hline
\end{tabular}


Table A-18: Estimators and p-values: Brasil (SIN: 607749), Period: 9/2000-12/2002 (28 Observations)

\begin{tabular}{|l|c|c|c|}
\hline Bond & $\alpha$ & $\beta$ & $R^{2}$ \\
\hline BOND 1 & $-0,06(0,90)$ & $0,99(0,00)$ & 0,99 \\
\hline BOND 2 & $-2,48(0,15)$ & $1,01(0,00)$ & 0,99 \\
\hline BOND 3 & $-2,51(0,14)$ & $1,01(0,00)$ & 0,99 \\
\hline BOND 4 & $0,71(0,57)$ & $0,98(0,00)$ & 0,99 \\
\hline BOND 5 & $4,87(0,02) * *$ & $0,28(0,00)$ & 0,95 \\
\hline BOND 6 & $2,91(0,19)$ & $0,29(0,00)$ & 0,94 \\
\hline BOND 7 & $2,90(0,19)$ & $0,29(0,00)$ & 0,94 \\
\hline BOND 8 & $4,72(0,04) * *$ & $0,27(0,00)$ & 0,94 \\
\hline
\end{tabular}

Table A-19: Estimators and p-values: Indonesia (SIN: 485500), Period: 1/1989-9/1993 (57 observations)

\begin{tabular}{|l|c|c|c|}
\hline Bond & $\alpha$ & $\beta$ & $R^{2}$ \\
\hline BOND 1 & $0,59(0,10) *$ & $1,02(0,00)$ & 0,97 \\
\hline BOND 2 & $1,01(0,46)$ & $1,13(0,00)$ & 0,72 \\
\hline BOND 3 & $0,98(0,46)$ & $1,13(0,00)$ & 0,72 \\
\hline BOND 4 & $1,37(0,06) *$ & $0,96(0,00)$ & 0,86 \\
\hline BOND 5 & $2,56(0,00) * * *$ & $0,68(0,00)$ & 0,76 \\
\hline BOND 6 & $2,67(0,09) *$ & $0,85(0,00)$ & 0,52 \\
\hline BOND 7 & $2,67(0,09) *$ & $0,85(0,00)$ & 0,52 \\
\hline BOND 8 & $3,08(0,00) * * *$ & $0,62(0,00)$ & 0,69 \\
\hline
\end{tabular}

Table A-20: Estimators and p-values: Mexico (SIN: 402280), Period: 10/1992-2/1996 (41 observations)

\begin{tabular}{|l|c|c|c|}
\hline Bond & $\alpha$ & $\beta$ & $R^{2}$ \\
\hline BOND 1 & $0,61(0,37)$ & $1,02(0,00)$ & 0,92 \\
\hline BOND 2 & $-1,46(0,58)$ & $1,07(0,00)$ & 0,47 \\
\hline BOND 3 & $-1,47(0,57)$ & $1,07(0,00)$ & 0,47 \\
\hline BOND 4 & $1,38(0,49)$ & $1,09(0,00)$ & 0,61 \\
\hline BOND 5 & $2,92(0,00) * * *$ & $0,63(0,00)$ & 0,74 \\
\hline BOND 6 & $0,76(0,78)$ & $0,72(0,00)$ & 0,26 \\
\hline BOND 7 & $0,76(0,78)$ & $0,71(0,00)$ & 0,26 \\
\hline BOND 8 & $3,09(0,03) * *$ & $0,68(0,00)$ & 0,56 \\
\hline
\end{tabular}


Table A-21: Estimators and p-values: Mexico (SIN: 130890), Period: 5/1996-12/2002 (80 observations)

\begin{tabular}{|l|c|c|c|}
\hline Bond & $\alpha$ & $\beta$ & $R^{2}$ \\
\hline BOND 1 & $1,53(0,00) * * *$ & $1,02(0,00)$ & 0,99 \\
\hline BOND 2 & $3,41(0,014) * *$ & $1,03(0,00)$ & 0,91 \\
\hline BOND 3 & $2,34(0,01)^{* * *}$ & $1,03(0,00)$ & 0,96 \\
\hline BOND 4 & $1,47(0,07) *$ & $1,03(0,00)$ & 0,97 \\
\hline BOND 5 & $4,16(0,00) * * *$ & $0,49(0,00)$ & 0,90 \\
\hline BOND 6 & $5,01(0,00) * * *$ & $0,55(0,00)$ & 0,81 \\
\hline BOND 7 & $4,89(0,00) * * *$ & $0,55(0,00)$ & 0,82 \\
\hline BOND 8 & $3,94(0,00) * * *$ & $0,48(0,00)$ & 0,87 \\
\hline
\end{tabular}

Table A-22: Estimators and p-values: Turkey (SIN: 485678), Period: 1/1989-9/1995 (81 observations)

\begin{tabular}{|l|c|c|c|}
\hline Bond & $\alpha$ & $\beta$ & $R^{2}$ \\
\hline BOND 1 & $0,20(0,53)$ & $1,00(0,00)$ & 0,99 \\
\hline BOND 2 & $0,11(0,95)$ & $0,94(0,00)$ & 0,78 \\
\hline BOND 3 & $-0,32(0,85)$ & $0,94(0,00)$ & 0,78 \\
\hline BOND 4 & $0,42(0,78)$ & $0,99(0,00)$ & 0,83 \\
\hline BOND 5 & $3,09(0,00) * * *$ & $0,54(0,00)$ & 0,85 \\
\hline BOND 6 & $2,60(0,16)$ & $0,50(0,00)$ & 0,45 \\
\hline BOND 7 & $2,60(0,16)$ & $0,50(0,00)$ & 0,45 \\
\hline BOND 8 & $3,14(0,04) * *$ & $0,52(0,00)$ & 0,57 \\
\hline
\end{tabular}

Table A-23: Estimators and p-values: Turkey (SIN: 129180), Period: 1/1996-7/1998 (31 observations)

\begin{tabular}{|l|c|c|c|}
\hline Bond & $\alpha$ & $\beta$ & $R^{2}$ \\
\hline BOND 1 & $1,14(0,012) * *$ & $0,98(0,00)$ & 0,93 \\
\hline BOND 2 & $6,66(0,03) * *$ & $0,91(0,01)$ & 0,20 \\
\hline BOND 3 & $3,79(0,00) * * *$ & $1,06(0,00)$ & 0,81 \\
\hline BOND 4 & $0,87(0,36)$ & $0,98(0,00)$ & 0,74 \\
\hline BOND 5 & $2,72(0,00)^{* * *}$ & $0,46(0,00)$ & 0,58 \\
\hline BOND 6 & $5,58(0,00)^{* * *}$ & $0,59(0,00)$ & 0,45 \\
\hline BOND 7 & $5,44(0,00)^{* * *}$ & $0,58(0,00)$ & 0,46 \\
\hline BOND 8 & $2,58(0,00) * * *$ & $0,47(0,00)$ & 0,44 \\
\hline
\end{tabular}


Table A-24: Estimators and p-values: Venezuela (SIN: 411810), Period: 2/1994-9/2000 (80 observations)

\begin{tabular}{|l|c|c|c|}
\hline Bond & $\alpha$ & $\beta$ & $R^{2}$ \\
\hline BOND 1 & $-0,25(0,53)$ & $1,01(0,00)$ & 0,99 \\
\hline BOND 2 & $-2,36(0,08) *$ & $0,99(0,00$ & 0,94 \\
\hline BOND 3 & $-2,37(0,07) *$ & $0,99(0,00)$ & 0,95 \\
\hline BOND 4 & $-0,28(0,83)$ & $0,94(0,00)$ & 0,94 \\
\hline BOND 5 & $3,17(0,00) * * *$ & $0,39(0,00)$ & 0,88 \\
\hline BOND 6 & $0,87(0,56)$ & $0,42(0,00)$ & 0,70 \\
\hline BOND 7 & $0,87(0,55)$ & $0,42(0,00)$ & 0,71 \\
\hline BOND 8 & $2,79(0,03) * *$ & $0,33(0,00)$ & 0,68 \\
\hline
\end{tabular}

\subsection{Hurdle Rates on GDP-linked Bonds and Existing Bonds and Derived Risk Premiums}

The following tables give an overview of the minimum rates that government bonds and simulated GDP-linked bonds need to generate in order to be adopted into international bond portofolios. The bond portofolios are represented through Indices from JP Morgan; each respectively comprised of world-wide (JP1) investment, investment in the eurozone (JP2) as well as in the JP EMI+Brady Bond Index (JP3).

The difference between the minimum rate of return for present government bonds and a GDP-linked bond indicates the maximum risk premium for a GDP-linked bond in order for it to be preferred over government bonds when making a decision on which one of these two to integrate into the index. The values shown in column 5 refer to the JP Morgan Global Index. The maximal allowable risk premium is recorded in basis points.

Column 6 contains estimations pertaining to GDP-linked bonds risk premium from Borensztein and Mauro (2002). The derived risk premiums relate to potential diversification of GDP risk in GDP-linked bonds. In this case we use the CAPM formula where risk premium $=\beta E\left(r_{M^{-}} r\right) . E(r)$ is the expected value of the risk free rate and $E\left(r_{M}\right)$ is the expected value of a similar portfolio. The parameter $\beta$ gives the linear relation between GDP in the country emitting the bond and the portfolio used as a reference. The range presented in column 6 for estimating the required risk premium shows the lowest and highest possible value of the risk premium when using a $\beta$ estimator as suggested in Borensztein and Mauro (2002, Table 1b, p. 13) for estimating World GDP and real equity prices. 
These calculations are based on a risk-free interest rate of $3 \%$ as well as an expected return on the (nominal) world equity index and nominal world GDP of $8 \%$. Comparing the maximum risk premium in column 5 with the estimations in column 6 reveals whether the range of risk premiums suggested by Borensztein and Mauro is compatible with our derived upper boundaries of maximum risk premiums.

Table A-25: Hurdle rate to enter index and risk premium

Brasil (SIN: 614414), Period: 2/2001-12/2002 (23 Observations)

\begin{tabular}{|c|c|c|c|c|c|}
\hline & JP1 & JP2 & JP3 & $\begin{array}{l}\text { Maximum risk premium } \\
\text { using JP Global (JP1) as } \\
\text { reference }\end{array}$ & $\begin{array}{c}\text { BM-risk } \\
\text { premium World }\end{array}$ \\
\hline Bond & 4,15 & $-19,6$ & 7,94 & -- & -- \\
\hline BOND 1 & 4,22 & $-19,8$ & 7,91 & $-7 \mathrm{Bp}$ & \multirow[t]{8}{*}{$44-952$ Bp } \\
\hline BOND 2 & 4,23 & $-20,0$ & 7,83 & $-8 \mathrm{Bp}$ & \\
\hline BOND 3 & 4,39 & $-19,9$ & 7,83 & $-24 \mathrm{Bp}$ & \\
\hline BOND 4 & 4,38 & $-21,44$ & 7,93 & $-23 \mathrm{Bp}$ & \\
\hline BOND 5 & 3,59 & $-2,78$ & 5,23 & $+56 \mathrm{Bp}$ & \\
\hline BOND 6 & 3,75 & $-2,52$ & 5,11 & $+40 \mathrm{Bp}$ & \\
\hline BOND 7 & 3,75 & $-2,52$ & 5,11 & $+40 \mathrm{Bp}$ & \\
\hline BOND 8 & 3,71 & $-3,95$ & 5,24 & $+44 \mathrm{Bp}$ & \\
\hline
\end{tabular}

Table A-26: Hurdle rate to enter index and risk premium,

Brasil (SIN: 607749), Periode: 9/2000-12/2002 (28 Observations)

\begin{tabular}{|l|c|c|c|c|c|}
\hline & JP1 & JP2 & JP3 & $\begin{array}{c}\text { Maximum risk premium } \\
\text { using JP Global (JP1) as } \\
\text { reference }\end{array}$ & $\begin{array}{c}\text { BM-risk } \\
\text { premium World }\end{array}$ \\
\hline Bond & 3,42 & $-13,24$ & 5,80 & -- & -- \\
\hline BOND 1 & 3,43 & $-13,22$ & 5,79 & $-1 \mathrm{Bp}$ & \multirow{2}{*}{$44-952 \mathrm{Bp}$} \\
\hline BOND 2 & 3,52 & $-13,71$ & 5,80 & $-10 \mathrm{Bp}$ & \\
\hline BOND 3 & 3,52 & $-13,72$ & 5,80 & $-10 \mathrm{Bp}$ & \\
\hline BOND 4 & 3,39 & $-13,30$ & 5,77 & $+3 \mathrm{Bp}$ & \\
\cline { 1 - 3 } BOND 5 & 3,65 & 0,35 & 4,40 & $-23 \mathrm{Bp}$ & \\
\hline BOND 6 & 3,74 & $-0,06$ & 4,41 & $-32 \mathrm{Bp}$ & \\
\hline BOND 7 & 3,74 & $-0,07$ & 4,41 & $-32 \mathrm{Bp}$ & \\
\hline BOND 8 & 3,62 & 0,17 & 4,40 & $-20 \mathrm{Bp}$ & \\
\hline
\end{tabular}


Table A-27: Hurdle rate to enter index and risk premium Indonesia (SIN: 485500), Period: 1/1989-9/1993 (57 Observations)

\begin{tabular}{|c|c|c|c|c|}
\hline & JP1 & JP2 & $\begin{array}{l}\text { Maximum risk premium using JP } \\
\text { Global (JP1) as reference }\end{array}$ & $\begin{array}{l}\text { BM-risk } \\
\text { premium World }\end{array}$ \\
\hline Bond & 9,15 & 8,85 & -- & -- \\
\hline BOND 1 & 9,14 & 8,23 & $+1 \mathrm{Bp}$ & \multirow[t]{8}{*}{$-60-506 \mathrm{Bp}$} \\
\hline BOND 2 & 9,11 & 8,74 & $+4 \mathrm{Bp}$ & \\
\hline BOND 3 & 9,11 & 8,74 & $+4 \mathrm{Bp}$ & \\
\hline BOND 4 & 9,15 & 8,88 & 0 & \\
\hline BOND 5 & 9,19 & 8,84 & $-4 \mathrm{Bp}$ & \\
\hline BOND 6 & 9,15 & 8,75 & 0 & \\
\hline BOND 7 & 9,15 & 8,75 & 0 & \\
\hline BOND 8 & 9,20 & 8,91 & $-5 \mathrm{Bp}$ & \\
\hline
\end{tabular}

Table A-28: Hurdle rate to enter index and risk premium

Mexico (SIN: 402280), Period: 10/1992-2/1996 (41 observations)

\begin{tabular}{|c|c|c|c|c|c|}
\hline & JP1 & JP2 & JP3 & $\begin{array}{c}\text { Maximum risk premium } \\
\text { using JP Global (JP1) as } \\
\text { reference }\end{array}$ & $\begin{array}{c}\text { BM-risk } \\
\text { premium World }\end{array}$ \\
\hline Bond & 7,37 & 7,57 & 7,76 & -- & -- \\
\hline BOND 1 & 7,37 & 7,52 & 7,66 & 0 & \multirow[t]{8}{*}{$36-358 \mathrm{Bp}$} \\
\hline BOND 2 & 7,38 & 7,42 & 7,43 & $-1 \mathrm{Bp}$ & \\
\hline BOND 3 & 7,38 & 7,42 & 7,43 & $-1 \mathrm{Bp}$ & \\
\hline BOND 4 & 7,37 & 7,50 & 7,63 & 0 & \\
\hline BOND 5 & 7,37 & 7,50 & 7,55 & 0 & \\
\hline BOND 6 & 7,37 & 7,39 & 7,32 & 0 & \\
\hline BOND 7 & 7,38 & 7,39 & 7,33 & 0 & \\
\hline BOND 8 & 7,37 & 7,51 & 7,60 & 0 & \\
\hline
\end{tabular}


Table A-29: Hurdle rate to enter index and risk premium

Mexico (SIN: 130890), Period: 5/1996-12/2002 (80 observations)

\begin{tabular}{|l|c|c|c|c|c|}
\hline & JP1 & JP2 & JP3 & $\begin{array}{c}\text { Maximum risk premium } \\
\text { using JP Global (JP1) as } \\
\text { reference }\end{array}$ & $\begin{array}{c}\text { BM-risk } \\
\text { premium World }\end{array}$ \\
\hline Bond & 4,05 & 4,28 & 8,06 & -- & -- \\
\hline BOND 1 & 4,21 & 4,46 & 8,13 & $-16 \mathrm{Bp}$ & \multirow{2}{*}{$36-358 \mathrm{Bp}$} \\
\hline BOND 2 & 4,62 & 4,95 & 8,18 & $-57 \mathrm{Bp}$ & \\
\hline BOND 3 & 4,61 & 4,97 & 8,17 & $-56 \mathrm{Bp}$ \\
\hline BOND 4 & 4,09 & 4,13 & 8,11 & $-4 \mathrm{Bp}$ \\
\hline BOND 5 & 4,46 & 5,22 & 5,95 & $-41 \mathrm{Bp}$ \\
\hline BOND 6 & 4,85 & 5,65 & 6,22 & $-80 \mathrm{Bp}$ \\
\hline BOND 7 & 4,84 & 5,62 & 6,21 & $-79 \mathrm{Bp}$ \\
\hline BOND 8 & 4,36 & 4,97 & 5,89 & $-31 \mathrm{Bp}$ \\
\hline
\end{tabular}

Table A-30: Hurdle rate to enter index and risk premium

Turkey (SIN: 485678), Period: 1/1989-9/1995 (81 observations)

\begin{tabular}{|c|c|c|c|c|}
\hline & JP1 & JP2 & $\begin{array}{l}\text { Maximum risk premium using JP } \\
\text { Global (JP1) as reference }\end{array}$ & $\begin{array}{c}\text { BM-risk } \\
\text { premium World }\end{array}$ \\
\hline Bond & 8,11 & 8,26 & -- & -- \\
\hline BOND 1 & 8,08 & 8,21 & $+3 \mathrm{Bp}$ & \multirow[t]{8}{*}{$-6-295$ Bp } \\
\hline BOND 2 & 7,87 & 7,91 & $+24 \mathrm{Bp}$ & \\
\hline BOND 3 & 7,91 & 7,92 & $+20 \mathrm{Bp}$ & \\
\hline BOND 4 & 7,95 & 8,05 & $+16 \mathrm{Bp}$ & \\
\hline BOND 5 & 8,16 & 8,21 & $-5 \mathrm{Bp}$ & \\
\hline BOND 6 & 7,99 & 7,81 & $+12 \mathrm{Bp}$ & \\
\hline BOND 7 & 7,99 & 7,81 & $+12 \mathrm{Bp}$ & \\
\hline BOND 8 & 8,05 & 8,11 & $+6 \mathrm{Bp}$ & \\
\hline
\end{tabular}


Table A-31: Hurdle rate to enter index and risk premium

Turkey (SIN: 129180), Period: 1/1996-7/1998 (31 observations)

\begin{tabular}{|l|c|c|c|c|c|}
\hline & JP1 & JP2 & JP3 & $\begin{array}{c}\text { Maximum risk premium } \\
\text { using JP Global (JP1) as } \\
\text { reference }\end{array}$ & $\begin{array}{c}\text { BM-risk } \\
\text { premium World }\end{array}$ \\
\hline Bond & 5,55 & 6,14 & 5,70 & -- & -- \\
\hline BOND 1 & 5,42 & 5,89 & 5,68 & $+13 \mathrm{Bp}$ & \multirow{2}{*}{$-6-295 \mathrm{Bp}$} \\
\hline BOND 2 & 6,18 & 7,15 & 6,80 & $+63 \mathrm{Bp}$ & \\
\hline BOND 3 & 5,49 & 6,15 & 5,76 & $+50 \mathrm{Bp}$ \\
\hline BOND 4 & 5,05 & 5,27 & 5,45 & $+32 \mathrm{Bp}$ \\
\hline BOND 5 & 5,23 & 5,71 & 5,37 & $+27 \mathrm{Bp}$ \\
\hline BOND 6 & 5,28 & 5,92 & 5,50 & $+27 \mathrm{Bp}$ \\
\hline BOND 7 & 5,28 & 5,91 & 5,49 & $+68 \mathrm{Bp}$ \\
\hline BOND 8 & 4,87 & 5,11 & 5,15 & \\
\hline
\end{tabular}

Table A-32: Hurdle rate to enter index and risk premium

Venezuela (SIN: 411810), Period: 2/1994-9/2000 (80 observations)

\begin{tabular}{|c|c|c|c|c|c|}
\hline & JP1 & JP2 & JP3 & $\begin{array}{l}\text { Maximum risk premium } \\
\text { using JP Global (JP1) as } \\
\text { reference }\end{array}$ & $\begin{array}{c}\text { BM-risk } \\
\text { premium World }\end{array}$ \\
\hline Bond & 4,32 & 4,59 & 7,71 & -- & -- \\
\hline BOND 1 & 4,35 & 4,62 & 7,78 & $-3 \mathrm{Bp}$ & \multirow[t]{8}{*}{$13-232 \mathrm{Bp}$} \\
\hline BOND 2 & 4,51 & 4,78 & 7,93 & -19 Bp & \\
\hline BOND 3 & 4,49 & 4,78 & 7,91 & $-17 \mathrm{Bp}$ & \\
\hline BOND 4 & 4,46 & 4,61 & 7,56 & $-14 \mathrm{Bp}$ & \\
\hline BOND 5 & 4,99 & 5,28 & 6,16 & $-67 \mathrm{Bp}$ & \\
\hline BOND 6 & 5,10 & 5,40 & 6,41 & -78 Bp & \\
\hline BOND 7 & 5,08 & 5,40 & 6,40 & $-76 \mathrm{Bp}$ & \\
\hline BOND 8 & 5,13 & 5,29 & 6,00 & $-81 B p$ & \\
\hline
\end{tabular}

